\title{
THE IMPORTANCE OF BEING EARNEST: SPELLING OF NAMES, EU CITIZENSHIP AND FUNDAMENTAL RIGHTS
}

\author{
Egle Dagilyte, Panos Stasinopoulos, Adam Łazowski*
}

\begin{abstract}
Summary: Names are central elements of people's identities: they distinguish them from other individuals and play an important role in human self-determination. Names and their spelling reach, from time to time, national and European courtrooms. The European Union is no exception in this respect, as the jurisprudence of the Court of Justice proves. Unlike the European Court of Human Rights, the Luxembourg court avoids looking at the right to one's name through the prism of fundamental rights but opts for internal market and EU citizenship reasoning. This article puts into context one of the latest EU citizenship cases on the right to one's name, originating from the (lack of) ethnic minority rights protection in Lithuania. The Runevič-Vardyn case, in which the Court of Justice was called to balance EU citizens' fundamental rights against national constitutional traditions to protect state language, also highlights the political and diplomatic tensions between Poland and Lithuania - two 'young' Member States with their unique post-Soviet history. This is only one of the many examples illustrating the intricate ethnic minority rights issues in many EU bordering Member States, which raises wider questions about the future of European integration. Given the current national reform on the spelling of names in identity documents in Lithuania, it may well be that the change to improve the protection to one's right to identity can come from within. The authors, however, propose that the Court takes a more coherent fundamental rights and proportionality approach on this matter. Hence, as a way out, they put forward a proposal for inclusive residence-based EU citizenship that is underpinned by the substantive equality of all EU citizens, no matter what their ethnic origin or mother tongue.
\end{abstract}

\footnotetext{
Dr Egle Dagilyte is Senior Lecturer in Law, Anglia Law School, Anglia Ruskin University, and Fellow of the Centre of European Law, King's College London. Dr Panos Stasinopoulos is Fellow of the Centre of European Law, King's College London and Commissioning Advisor, Ministry of Justice (all views expressed in this article are the author's own and do not represent the views of the Ministry or any other agent, body, or department of HM's Government). Prof Dr Adam Łazowski is Professor of EU Law, Westminster Law School, University of Westminster. The authors are thankful to Dimitry Kochenov and Richard Lang for constructive comments that helped improve this article. Our thanks also go to the participants of various conferences and workshop where earlier versions of this article were presented: 'Re-Inventing Eastern Europe' (Prague 2013); UACES Annual Conference (Passau 2012); JMCE Research Student Workshop 'The Future of the European Union - Challenges and Opportunities' (London 2012); CRiL Summer Legal Research Seminar 'Get Me to the Court on Time! Matrimonial Causes - and Effects - in UK and EU Law' (Luton 2012). The usual disclaimer applies.
} 


\section{Introduction}

The right to one's name is found explicitly regulated in a handful of legal acts. In general terms it is protected in international, national and EU law qua the right to human dignity, the right to private and family life, freedom of expression, and non-discrimination on the grounds of ethnic origin. If one were to assume that each human being has a right to determine what his or her cultural-ethnic identity is, this self-determination includes the individual choice for their name to be spelt in the language they believe is part of their heritage. After all, 'linguistic regulation and the promotion of particular languages naturally bring about indirect discrimination on the basis of ethnicity'. ${ }^{1}$ At the same time, however, it should be acknowledged that such a right would fall within the category of qualified fundamental rights, ie rights that can be limited if they are in conflict with the rights of others. Conflicting legitimate interests could include collective rights, such as the right to protect a language. In situations where individual rights come into tension with collective rights, legislators and judges have to resolve conflicts by balancing or ranking the rights in question. No doubt, there is a plethora of dilemmas to face. In the EU context, this includes, inter alia, where and how this balance should be struck. Should national courts, when doing so, consider not only individual liberties (ie the right to one's name), but also the policy implications that these decisions may have for the relations, including diplomatic ones, between Member States? Should the centre of gravity be on fundamental rights or EU citizenship? What implications may prioritising national social contracts, such as the use of a common language by a given society, have on the unity of the European Union?

It is notable that the rules on spelling of names are not within the competences attributed to the European Union. ${ }^{2}$ A contrario, they remain within the competence of the Member States. At the same time, however, the domestic authorities have the obligation to use their powers taking account of EU law. This, as experience proves, is not only a theoretical proposition, but a matter of practical importance, which has already led to the development of a particular 'breed' of EU law free movement cases. Although the jurisprudence of the Court of Justice is not very prolific, a clear picture emerges: national rules on the spelling of EU citizens' names may constitute an obstacle to exercising their free movement rights. Even before the emergence of EU citizenship, the case law of the Court of Justice addressed how a different spelling could be deemed to be harmful

\footnotetext{
1 D Kochenov and others, 'Do Professional Linguistic Requirements Discriminate? A Legal Analysis: Estonia and Latvia in the Spotlight' (2011) 10 EYMI 137.

2 See B De Witte and M Claes, 'Competences: Codification and Contestation' in A Łazowski and S Blockmans (eds), Research Handbook on EU Institutional Law (Edward Elgar 2016).
} 
for one's business, ${ }^{3}$ while in other cases the correct name itself was a matter of identity. ${ }^{4}$ It is worth noting that from the start the Luxembourg court focused on the internal market, and later directed its attention to the EU citizenship dimension of these cases. However, the judges shied away from exploring the fundamental rights angle. This is evident even in the post-Lisbon Treaty case Runevič-Vardyn, ${ }^{5}$ where the centre of gravity, at least in theoretical terms, could have been the binding Charter of Fundamental Rights. As argued in this article, exploring further EU citizenship was a safer option for the Court, as it allowed it to demonstrate the continuity of a particular line of case law and, by the same token, to strengthen the EU citizenship paradigm. At the same time, the judges did not risk being accused of competence creep qua the Charter.

This article focuses largely on the Runevič-Vardyn case, which is an interesting development in a number of ways. To begin with, it is one of the most recent cases about the spelling of names to have reached the Court of Justice, raising questions of academic and practical importance. Furthermore, it is a case with an intriguing political background. It raised public debate in Lithuania and in Poland - two neighbouring Member States which joined the Union in 2004 and which share close historical and cultural roots, as well as bilateral political disagreements. Arguably, this particular reference for a preliminary ruling caught the Court of Justice between a rock and a hard place, forcing the judges to employ a 'sense and sensibility' approach. This is clearly visible in both the Opinion of Advocate General Jääskinen and the judgment of the Court of Justice.

The analysis that follows is structured in the following way. First, we explore the broad picture of how the right to one's name is regulated in international and EU law. The point of departure is several international conventions dealing with the right in question (section 2). This leads to an evaluation of the EU acquis, including the jurisprudence of the Court of Justice (section 3). In the next step the political legal background of the Runevič-Vardyn case is analysed (section 4). This part of the article sets the stage for an analysis of the case itself, as well as its importance for Polish-Lithuanian relations and the challenges it may pose for the future of European integration. In the last section of the article, we provide the necessary conceptual framework for a better understanding of the difficulty in reconciling fundamental freedoms and national constitutional traditions. The analysis focuses on EU citizenship serving as a facilitator

\footnotetext{
3 Case C-168/91 Christos Konstantinidis v Stadt Altensteig - Standesamt and Landratsamt Calw - Ordnungsamt ECLI:EU:C:1993:115.

4 Case C-208/09 Ilonka Sayn-Wittgenstein v Landeshauptmann von Wien ECLI:EU:C: 2010:806.

5 Case C-391/09 Malgožata Runevič-Vardyn and Łukasz Paweł Wardyn v Vilniaus miesto savivaldybès administracija and Others ECLI:EU:C:2011:291.
} 
for integration and on the interaction of the Court and national courts vis-à-vis fundamental rights in the post-Lisbon legal environment of the European Union (section 5).

\section{The right to one's name in international and EU law}

\subsection{A preliminary overview}

As already mentioned in the introduction, the right to one's name is provided for in several international treaties. A brief reminder is fitting that in a great majority of cases it is not a tailor-made explicitly regulated right, but rather falls within the parameters of human dignity, the right to private and family life, freedom of expression, and non-discrimination on the grounds of ethnic origin.

In Europe, a leading international agreement that regulates the spelling of names of those belonging to national minorities in their original language is the Framework Convention for the Protection of National Minorities (FCNM). ${ }^{6}$ It was prepared in the mid 1990s under the auspices of the Council of Europe. ${ }^{7}$ When this article went to print, out of twenty-eight EU Member States, twenty-four had ratified it $^{8}$ and three are signatories though have not yet completed the ratification procedures. ${ }^{9}$ France, one of the largest Member States, has neither signed nor ratified the Convention. Bearing in mind the Runevič-Vardyn case discussed in detail in this article, it is worth noting that both Lithuania and Poland became parties to the Convention in 2000. In terms of substance, Art $11(1)$ of the Convention merits attention. It provides that 'Every person belonging to a national minority has the right to use his or her surname (patronym) and first names in the minority language and the right to official recognition of them'. This provision also outlines that the right in question is regulated 'according to modalities provided for in [the] legal system [of the state Parties] $\cdot .{ }^{10}$ Arguably, it echoes the margin of apprecia-

\footnotetext{
$6 \quad$ Furthermore, it is worth noting that Article 10(5) of the European Charter for Regional or Minority Languages provides: 'The Parties undertake to allow the use or adoption of family names in the regional or minority languages, at the request of those concerned'. However, not all Member States are parties to it; hence its relevance is limited.

7 For a comprehensive analysis, see M Weller, The Rights of Minorities. A Commentary on the European Framework Convention for the Protection of National Minorities (OUP 2005).

8 Bulgaria (1999), Cyprus (1996), the Czech Republic (1997), Denmark (1997), Estonia (1997), Finland (1997), Germany (1997), Hungary (1995), Ireland (1999), Italy (1997), Latvia (2005), Liechtenstein (1997), Lithuania (2000), Malta (1998), the Netherlands (2005), Poland (2000), Portugal (2002), Romania (1995), the Slovak Republic (1995), Slovenia (1998), Spain (1995), Sweden (2000), the United Kingdom (1998).

9 Belgium (2001), Greece (1997), Luxembourg (1995).

10 Art 11(1) FCNM. For a commentary, see F de Varennes, 'Use of Names and Signs' in M Weller (ed), The Rights of Minorities: A Commentary on the European Framework Convention for the Protection of National Minorities (OUP 2005) 329-363.
} 
tion doctrine adopted by the European Court of Human Rights, which allows national idiosyncrasies to co-exist, as long as they do not breach the ECHR obligations. ${ }^{11}$ The Explanatory Report of the Framework Convention confirms this view, ${ }^{12}$ and allows the Parties to "use the alphabet of their official language to write the name(s) of a person belonging to a national minority in its phonetic form'. ${ }^{13}$ The latter is the implementation of the Convention favoured by Lithuania. ${ }^{14}$

The right to one's name also has prominence in general human rights conventions. At the global level, the UN International Covenant on Civil and Political Rights is worth attention here as it provides in Article 24(2) for an explicit right to have a name. ${ }^{15}$ Indisputably, the most important legal act of that kind applicable in Europe is the European Convention on Human Rights. ${ }^{16}$ It makes no specific reference to the right to one's name but, at the same time, the jurisprudence of the European Court of Human Rights proves that the right in question falls within the parameters of the right to family life guaranteed in Article $8 .{ }^{17}$ Although the European Union is a party to neither of those international conventions, they may have an impact on EU law qua the Charter of Fundamental Rights or general principles of EU law (as per Article $6 \mathrm{TEU}) .{ }^{18}$ This will change when the European Union accedes to the ECHR, which, as a result of Opinion $2 / 13$ of the Court of Justice, will now be considerably delayed. ${ }^{19}$

\footnotetext{
11 See Mentzen $v$ Latvia App no 71074/01 (ECtHR 7 December 2004) that adopts a similar flexible approach.

12 'In view of the practical implications of this obligation, the provision is worded in such a way as to enable Parties to apply it in the light of their own particular circumstances', para 68. 13 ibid.

14 The Advisory Committee that evaluates the implementation of the Convention was critical of the Lithuanian approach, but did not establish any breach of the Convention. See A Račkauskaitè, 'Tautinėms Mažumoms Priklausančiu Asmenu Vardu Ir Pavardžiu Vartojimas: Tarptautinė Ir Lietuvos Respublikos Praktika [The Right to Use Names and Surnames in Minority Languages: International Practice and the Practice of the Republic of Lithuania]' (2011) 3 Soc Stud 365, 375.

15 See further, inter alia, S Joseph and others, The International Covenant on Civil and Political Rights: Cases, Materials, and Commentary (OUP 2004).

16 For a commentary, see, inter alia, C Grabenwarter, European Convention on Human Rights: Commentary (CH Beck-Hart-Nomos 2014).

17 Change of names: Burghartz $v$ Switzerland App no 16213/90 (ECtHR 22 February 1994); Stjerna $v$ Finland [1994] App no 18131/91 (ECtHR 25 November 1994). Naming children: Salonen $v$ Finland App no 27868/95 (ECtHR 2 July 1997); Guillot $v$ France App no 22500/93 (ECtHR 24 October 1993); Johansson v Finland App no 10163/02 (ECtHR 6 September 2007). Linguistic form of name: Mentzen $v$ Latvia App no 71074/01 (ECtHR 7 December 2004).

18 For an overview on how the Court 'discovered' the general principle of fundamental rights protection to grant rights, see P Craig and G De Burca, EU Law: Text, Cases, and Materials (OUP 2015) 383-84.

19 As per Article 6(1) TEU, the European Union will accede to the ECHR. An agreement to this end has been negotiated; however, in December 2014 the Court of Justice in Opinion 2/13 held that the draft agreement was not compatible with EU law, particularly Article
} 
As already noted, the law on the spelling of names of national minorities is the domain of the Member States; the European Union has no competence here. Consequentially, there is no secondary legislation harmonising the rules on the spelling of names of national minorities. ${ }^{20}$ However, as per well-established jurisprudence of the Court of Justice, the Member States - when exercising their domestic competence - must have regard to EU law. To put it differently, the primacy of EU law means that the Member States must ensure that their national laws do not infringe any rights granted to citizens of the European Union by EU law. ${ }^{21}$ In this context, the Charter of Fundamental Rights should be mentioned, as a large number of its provisions mirror the ECHR, including the right to family life, which is provided in Article 7 of the Charter. ${ }^{22}$ This, of course, does not mean that the European Union has a competence in the matter at hand, or that the right to one's name stemming from the Charter gives a self-sustained claim in national courts. As per Article 6 TEU, the Charter does not increase the competences of the European Union. This is confirmed in Article 51 of the Charter itself. Hence, in this context, the Charter may be only a useful tool for the interpretation of other provisions laid down in EU primary or secondary legislation. Furthermore, Article 51 of the Charter makes it clear that the Charter applies when the Member States implement EU law. ${ }^{23}$

CJEU case-law developments provide guidance on the matter. The Court, as we shall see, presumably because of evidence of the importance of the right to a name, included the right in its jurisprudence, but it did so by basing its judgments on fundamental (economic) freedoms, or the existence of an inconvenience in exercising the said freedoms. This, how-

6(1) TEU and Protocol No 8 to it. See further on the accession, P Gragl, The Accession of the European Union to the European Convention on Human Rights (Hart Publishing 2013). From a plethora of academic commentary on Opinion 2/13, see, inter alia, D Halberstam, "It's the Autonomy, Stupid!" A Modest Defense of Opinion 2/13 on EU Accession to the ECHR, and the Way Forward' (2015) 16 GLJ 105; Ch Krenn, 'Autonomy and Effectiveness as Common Concerns: A Path to ECHR Accession after Opinion 2/13' (2015) 16 GLJ 147; S Øby Johansen, 'The Reinterpretation of TFEU Article 344 in Opinion 2/13 and its Potential Consequences' (2015) 16 GLJ 169; A Łazowski and RA Wessel, 'When Caveats Turn into Locks: Opinion 2/13 on Accession of the European Union to the ECHR' (2015) 16 GLJ 179; S Peers, 'The EU's Accession to the ECHR: The Dream Becomes a Nightmare' (2015) 16 GLJ 213.

20 K Granickas, 'Tautiniu Mažumu Asmenvardžiu Rašymas Lietuvoje: Kuriuo Keliu Eiti? [The Spelling of Names of Ethnic Minorities in Lithuania: Which Road to Choose?]' Infolex. lt (14 June 2011).

21 Case C-135/08 Janko Rottman v Freistaat Bayern ECLI:EU:C:2010:104.

22 See, inter alia, J Vedsted-Hansen, 'Article 7 (Private Life, Home and Communications)' in S Peers and others (eds), The EU Charter of Fundamental Rights: A Commentary (CH BeckHart-Nomos 2014) 161-65.

23 For interpretation, see Case C-617/10 Åklagaren $v$ Hans Åkerberg Fransson ECLI:EU:C:2013:105. See further, inter alia, E Hancox, "The Meaning of "Implementing" EU Law under Article 51(1) of the Charter: Åkerberg Fransson’ (2013) 50 CML Rev 1411. 
ever, is where for the time being the journey ends. The case law below demonstrates this evolutionary trajectory.

\subsection{Jurisprudence of the Court of Justice}

\subsubsection{Introduction}

As the introduction to this paper has indicated, our names are central elements of our identities: they distinguish us from other individuals and play an important role in our self-determination. ${ }^{24}$ The Runevič-Vardyn case was not the first one to address such a potentially controversial issue. In fact, the first case to do so was resolved by the Court before EU citizenship was even established, which could be an indication that a notion of EU citizenship was present long before the Treaty of Maastricht cemented it. ${ }^{25}$ While all these cases are analysed in depth later in this article, at this stage it is fitting to provide readers with general background information as a point of departure for the discussion of Runevič-Vardyn.

\subsubsection{The Konstantinidis case}

In Konstantinidis, the Court of Justice considered the case of a Greek national residing in Germany, whose name's transliteration in Latin characters was not consistent with the name's phonetic pronunciation in Greek. ${ }^{26}$ Advocate General Jacobs argued that the right to have one's name spelt in accordance with one's wishes was a constitutional tradition of the Member States, and was a means to ensure the bearer's 'dignity, moral integrity, and sense of personal identity'. ${ }^{27}$ Various references in national constitutions to dignity, in conjunction with one's name, led the Advocate General to the conclusion that the right to a name was indeed a common constitutional tradition via its association with human dignity. ${ }^{28}$ The Court simply reiterated that that Member States could exercise their discretion when they decided how to transcribe a Greek name

\footnotetext{
24 The tactic of penal systems to remove prisoners' names and replace them with a number is evidence to this.

25 FG Jacobs, 'Citizenship of the European Union: A Legal Analysis' (2007) 13 ELJ 591; P Stasinopoulos, 'EU Citizenship as a Battle of the Concepts: Travailleur v Citoyen' (2012) 4 EJLS 74.

26 For an academic appraisal, see R Lawson, 'Case C-168/91, Christos Konstantinidis v Stadt Altensteig-Standesamt, Judgment of 30 March 1993 [1993] 3 CMLR 401' (1994) 31 CML Rev 395.

27 Para 39 of the Opinion.

28 See Case C-260/89 Elliniki Radiophonia Tiléorassi AE and Panellinia Omospondia Syllogon Prossopikou $v$ Dimotiki Etairia Pliroforissis and Sotirios Kouvelas and Nicolaos Avdellas and others ECLI:EU:C:1991:254. On the national constitutional importance of human dignity, see Case C-36/02 Omega Spielhallen- und Automatenaufstellungs-GmbH v Oberbürgermeisterin der Bundesstadt Bonn ECLI:EU:C:2004:614 and Case C-34/10 Oliver Brüstle v Greenpeace eV ECLI:EU:C:2011:669.
} 
using the Latin alphabet when introducing laws or other administrative measures, as long as this discretion did not infringe ${ }^{29}$ one's right to exercise fundamental freedoms. The CJEU essentially confirmed AG Jacobs' analysis on the existence of indirect discrimination, but did not, as the AG did, engage in a discussion of fundamental rights or arguments for an extended personal scope of the free movement of workers that sees humans not simply as production factors, ${ }^{30}$ a reasoning indicative of the later transition from the concept of a worker to that of a citizen.

\subsubsection{The Garcia Avello case}

The issue of names re-emerged in the post-citizenship and post-Martinez Sala ${ }^{31}$ period, in the Garcia Avello case. ${ }^{32} \mathrm{Mr}$ Avello and his Belgian wife applied to amend their children's names so that they consisted of two surnames, the father's and the mother's, as per Spanish custom. Belgian law did not allow for the said amendment, unless under exceptional circumstances. AG Jacobs included in his Opinion a passage on the pluralism of name regimes in the Union, demonstrating the difficulty of establishing a common ground at EU level. As in Konstantinidis, it was made clear that the Member States retained the right to regulate issues such as the one at hand; however, the Advocate General acknowledged both the potential practical difficulties which the children might encounter because of the various versions of their surname, and the fact that citizenship of the Union provided broader protection. The Court, indicat-

\footnotetext{
29 Infringement, or breach, is interpreted widely, often employing the 'market access' test. See 120/78 Rewe-Zentral AG v Bundesmonopolverwaltung für Branntwein ECLI:EU:C:1979:42 (the free movement of goods); Case C-76/90 Manfred Säger $v$ Dennemeyer \& Co Ltd, ECLI:EU:C:1991:331 (the free movement of services); Case C-55/94 Reinhard Gebhard $v$ Consiglio dell'Ordine degli Avvocati e Procuratori di Milano ECLI:EU:C:1995:411 (the freedom of establishment). AG Jacobs refereed to the test in Konstantinidis; see para 15 of the Opinion.

30 Para 24 of the Opinion.

31 Martinez Sala is the first case in which the Court referred to Union citizenship as a bearer of independent rights, and awarded rights to social benefits to a non-economically active EU citizen: Case C-85/96 Maria Martinez Sala v Freistaat Bayern ECLI:EU:C:1998:217. For an academic appraisal, see, inter alia, Ch Timmermans, 'Martinez Sala and Baumbast Revisited' in MP Maduro and L Azoulai (eds), The Past and Future of EU Law: The Classics of EU Law Revisited on the 50th Anniversary of the Rome Treaty (Hart Publishing 2010) 345; J Shaw, 'A View of the Citizenship Classics: Martinez Sala and Subsequent Cases on Citizenship of the Union' in Maduro and Azoulai (n 31) 356; AJ Menéndez, 'European Citizenship after Martínez Sala and Baumbast: Has European Law Become More Human But Less Social?' in Maduro and Azoulai (n 31) 363; C Closa Montero, 'Martínez Sala and Baumbast: An Institutionalist Analysis' in Maduro and Azoulai (n 31) 394.

32 Case C-148/02 Carlos Garcia Avello v Belgian State ECLI:EU:C:2003:539. For an academic appraisal, see, inter alia, T Ackermann, 'Case C-148/02, Carlos Garcia Avello v État Belge' (2007) 44 CML Rev 141; J Verlinden, 'European Court of Justice, Judgment of October 2, 2003, Case C-148/02, Carlos Garcia Avello v Etat Belge (The State of Belgium)' (2004) 11 CJEL 705.
} 
ing the importance of EU citizenship as a source of independent rights, ${ }^{33}$ also focused on the fact that the children were of dual nationality, which represents one of the two exceptions to the (traditional) wholly internal situation rule, ${ }^{34}$ thus extending both the material scope of EU citizenship rights to cover the issue of names and their personal scope. In an effort to protect the individual, in a manner previously seen in Carpenter, ${ }^{35}$ the Court undermined the need to establish an undisputed link between breach and exercise of EU rights; it was satisfied with the admission that a hypothetical barrier to free movement was a sufficient trigger. ${ }^{36}$ Both the judgment and the Opinion in Garcia Avello applied a strict proportionality test: it was argued that the justifications provided by Belgium for the Member State's inflexibility were not adequate: its aim to promote integration and ensure that no confusion arose regarding parentage and identity would not have been negatively affected by allowing Mr Avello and his wife to pass their surnames on to their children.

\subsubsection{The Grunkin and Paul case}

The third case on EU citizens' names, Grunkin and Paul, concerned a child of German nationality, Leonhard Matthias, who was born in Denmark (where the jus sanguinis principle applied) and who had been given the surnames of both parents (Grunkin-Paul). ${ }^{37}$ When the family moved to Germany, the local authorities refused to accept the name as registered by Danish authorities because, under German private law, offspring could take only one surname. Advocate General Sharpston in her Opinion argued the European space was more than a common market. In her examination of discrimination, the Advocate General acknowledged that the German measure was not discriminatory, but nevertheless infringed the general principle of equal treatment: although nationality was not an issue, there was discrimination based on residence. Following this analysis, it was established that failure to accept the hyphenated surname would be a future obstacle to the EU citizen's free movement rights. A detail that will be useful later on to understand Runevič-Vardyn

\footnotetext{
33 W Maas, 'Unrespected, Unequal, Hollow? Contingent Citizenship and Reversible Rights in the European Union' (2008) 15 CJEL 265.

34 The operative word is 'traditional'. Ever since the conception of the rule, according to which an intra-border movement has to take place in order for the application of EU rights to be triggered, more exceptions have been noted, of enough substance to argue that the Court's stance may be changing. See, indicatively, A Tryfonidou, 'In Search of the Aim of the EC Free Movement of Persons Provisions: Has the Court of Justice Missed the Point?' (2009) 46 CML Rev 1591.

35 Case C-60/00 Mary Carpenter $v$ Secretary of State for the Home Department ECLI:EU:C:2002:434

36 E Spaventa, 'From Gebhard to Carpenter: Towards A (non-) Economic European Constitution' (2004) 41 CML Rev 743.

37 Case C-353/06 Stefan Grunkin and Dorothee Regina Paul ECLI:EU:C:2008:559.
} 
is that in Grunkin and Paul the Lithuanian government in its submission argued that - in order to protect their national languages - Member States should not have to accept names as spelt by other countries. In this particular case, however, it was difficult to imagine how the German language would have been affected by the hyphenated surname. The Court's judgment was remarkably similar to Konstantinidis, in that it also applied an access to market test and failed to find objective justifications for the German practice: Germany's argument that this practice could achieve an element of 'certainty and continuity'38 was not sufficient.

\subsubsection{The Sayn-Wittgenstein case}

The last pre-Runevič-Vardyn case on the right to a name, Sayn-Wittgenstein, involved a question of national constitutional relevance. ${ }^{39}$ The post-Hapsburg Austrian constitution abolished all titles and privileges in an effort to create a republic, in effect prohibiting surnames denoting nobility. The appellant, an Austrian citizen who had been adopted as an adult in Germany and who ran a real-estate business selling castles and stately homes in Austria, had changed her name to reflect her adoption. The name included the element Fürstin von, which did not denote nobility in Germany, but did so in Austria. During the 15 years following her adoption, the Austrian authorities never challenged the validity of her name, and she was issued with a driving licence and established a business in Germany under her new name. Ms Sayn-Wittgenstein also renewed her (Austrian) passport without incident and received two birth certificates bearing her full surname. Thereafter, she was informed that Austrian authorities would have to remove the prefix Fürstin von from her name in the Austrian birth register. Advocate General Sharpston found no evidence of discrimination, but made it clear that having retrospectively to erase a component of a name could create various personal and professional inconveniences, especially as it had taken the Austrian authorities 15 years to realise their error. Although the AG's Opinion, while recognising the legitimate aim of the Austrian decision, seemed more sympathetic towards the individual, the Court was more equivocal: it held that the Austrian decision constituted a serious inconvenience for Ms Sayn-Wittgenstein and was a breach of the EU free movement provisions. Nevertheless, despite the strict analysis of breach under EU law, it found the Austrian rules justifiable under the public policy derogation.

\footnotetext{
38 Para 30.

39 For an academic appraisal, see, inter alia, LFM Besselink, 'Respecting Constitutional Identity in the EU: Case C-208/09, Ilonka Sayn-Wittgenstein v Landeshauptmann von Wien, Judgment of the Court (Second Chamber) of 22 December 2010' (2012) 49 CML Rev 671.
} 


\section{The Runevič-Vardyn case - progeny, substance and aftermath}

\subsection{Introduction}

The latest judgment dealing with the right to one's name was rendered by the Court of Justice in Runevič-Vardyn. For those not familiar with the political and legal idiosyncrasies of the case, it may remain just another judgment of the Court, touching upon a sensitive matter that is largely the domain of national law. Yet, there is more than meets the eye here. As explained below, this judgment has a peculiar background which is explored first, before we move on to a presentation of the case itself.

\subsection{Polish-Lithuanian relations: history and current problems}

While one could see that the national law may indeed limit one's human right to identity and private life (language being one of the elements of such identity), the matter presented in Runevič-Vardyn was not limited just to the ad hoc situation of two people of Polish ethnicity. The case continues to raise public debate both in Lithuania and in Poland, especially as regards the protection of minority rights. In order to understand the implications of the judgment on the diplomatic relations of both states, and the importance of such relations in the European integration process, it is essential to see where the deeper problems of mutual discontent lie. Might they be buried in the common history between the two Member States, starting from the Lublin Union in 1569 (which was the formation of the Polish-Lithuanian Commonwealth) to the current day? ${ }^{40}$

The interests of the Commonwealth ${ }^{41}$ that 'always took second place to the grievances of the magnate factions against the king', ${ }^{42}$ the military threats from Russia, and the 'spirit of capitulation' from King Stanislaw Augustus ${ }^{43}$ were the main reasons why the Polish-Lithuanian co-federation was not strong enough internally or externally, and why it ceased to exist in 1795. The land was then divided by Russia, Prussia, and the Austro-Hungarian Empire. During the foreign rule until the end of WWI, both nations sought inspiration in their history and language in order to become independent states. When in 1915 Germany occupied Lithuanian and Polish territories (the part of the greater Russian Empire territory

\footnotetext{
40 N Davies, God's Playground: A History of Poland, Volume 1: The Origins to 1795 (2nd edn, OUP 2005).

41 See the troublesome reform to introduce a modern (for those days) Constitution, which failed in 1791 (adopted only with one-third of the Sejm deputies present). Despite its unfortunate fate, the Constitution was praised by the Western countries and it was the second in the world (after the UK Constitution) to regulate citizens' rights and duties; see JA Gierowski, The Polish-Lithuanian Commonwealth in the XVIIIth Century: From Anarchy to Well-Organised State (Nakladem 1996) 231-55.

42 ibid 234.

43 ibid 260-61.
} 
known as the Ober-Ost), ${ }^{44}$ both Lithuania and Poland fought against German oppression, at the same time finding it difficult to agree about the land around the current south-eastern part of Lithuania, including the capital Vilnius, which continued to cause problems during 1920-1939. After 22 years of independence (1918-1940), 'Lithuania was seized by the Soviet Union during World War II, and border changes have left it with a Polish minority [of $7 \%$ ] of the population', ${ }^{45}$ which became quite influential in Lithuania's political and social life. The Polish minority 'enjoyed rather broad cultural autonomous rights in the Soviet Lithuania'; 46 it was part of the Communist regime and not in favour of the restoration of Lithuania's independence in the 1990s. At the same time, a quasi-independent contemporary Poland (not part of the Soviet Union but under its heavy influence) was left with an ethnic Lithuanian minority in the land bordering the south-east of current Lithuania (Suwałki).

As the winds of change swept Central and Eastern Europe, Lithuania gained independence, while Poland regained its sovereignty. ${ }^{47}$ Lithuania freed itself from the collapsing Soviet Union, while Poland ceased to be the latter's satellite state. ${ }^{48}$ The first step towards diplomatic relations between the two independent neighbours was the Treaty on Friendly Relations and Good Neighbourly Cooperation (TFRGNC), ${ }^{49}$ signed in April 1994. ${ }^{50}$ Article 13(2) of the Treaty ensured ethnic minorities in both states had the right (individually or collectively) to express, preserve, and develop their cultural, linguistic, and religious identity in a free manner and without any discrimination, while Article 14 of the Treaty further established that this included the right to use one's name and surname according to the sound of the ethnic minority language [emphasis added]. Detailed rules on personal names were to be set out in a special bilateral treaty; however, such a treaty has not been drafted until today. ${ }^{51}$ The

\footnotetext{
44 M Jučas and others, Lietuvos Istorija: Nuo Seniausiu Laiku Iki 1917 Metu [Lithuanian History: From the Oldest Ages to 1917] (Mokslas 1988) 176.

45 'Lithuania Hails EU Court Ruling in Spat Over Polish Names' (EUbusiness.com, 12 May 2011).

46 Ž Dambrauskaitè and others, 'Lithuanian-Polish Relations Reconsidered: A Constrained Bilateral Agenda or an Empty Strategic Partnership?' (2011) 26 LFPR 100, 128.

47 See further T Snyder, The Polish-Lithuanian Commonwealth Since 1989: National Narratives in Relations Among Poland, Lithuania, Belarus and Ukraine' (1998) 4 NEP 1; T Snyder, 'National Myths and International Relations: Poland and Lithuania, 1989-1994' (1995) 9 EEPS 317.

48 See, inter alia, G Stokes, The Walls Came Tumbling Down: The Collapse of Communism in Eastern Europe (OUP 1993); TG Ash, The Magic Lantern: The Revolution of '89 Witnessed in Warsaw, Budapest, Berlin and Prague (Atlantic Books 2014).

49 Treaty on Friendly Relations and Good Neighbourly Cooperation, UNTS Vol 1851 (2001) 1-31485, 3-50.

50 V Sirutavičius, 'Lithuanian-Polish Strategic Partnership: Genesis and Prospects' (2001) 7 LFPR 1.

51 One of the current reciprocal claims from Poland is for Lithuania to change its law in this regard because Poland has done so.
} 
TFRGNC also continued the commitments necessary for the future membership of NATO and the EU, which until 2010 acted as a distraction ${ }^{52}$ from the underlying unsolved issues of territories ${ }^{53}$ and minorities.

In the early years of independence, Poland concentrated on building foreign relations with the Visegrad countries. ${ }^{54}$ However, once an EU member, between 2007 and $2010^{55}$ it began forging alliances with Sweden, Germany and France, while Lithuania was looking for partnerships with the Baltic and Nordic countries. ${ }^{56}$ The mood of 'friendly cooperation' changed, especially after 9/11, which presented Poland and Lithuania with a competitive opportunity to prove their loyalty to the US, ${ }^{57}$ while Russia came to be seen by both as a partner in economic cooperation rather than as an enemy. ${ }^{58}$ This has obviously changed in the light of Russia's neo-imperialist policy and annexation of Crimea in 2014.

In the past ten years, the main points of disagreement between the two Member States have currently included not only the spelling of names and land restitution, ${ }^{59}$ but also a poor investment climate and politicised trade relations over the privatisation of PKN Orlen. ${ }^{60}$ Amendments to the Law on Education approved by the Seimas in March 2011 are also not satisfactory in the eyes of Poland, even though, outside Poland, 'Lithuania is probably the only place in the world where education

\footnotetext{
52 A Valionis and others, 'From Solidarity to Partnership: Lithuanian-Polish Relations 1988-1998' (1998) 2 LFPR 7.

53 Current eastern territories of Lithuania and the western parts of Belarus and Ukraine, known as Kresy/Eastern Kresy; see Dambrauskaitè and others (n 46) 102.

54 Hungary, Slovakia and the Czech Republic; see ibid 104.

55 Including, inter alia, the opt-outs from the Treaty of Lisbon, developing and finalising the Eastern Partnership Initiative, Jerzy Buzek's election as the President of the European Parliament; see ibid 113.

56 ibid 114.

57 Poland's and Lithuania's 'support for US military intervention in Iraq and allegations of hosting interrogation camps on Polish and Lithuanian soil ... create[d] a controversial image of both countries within the EU'; ibid 107-08. See also D Farwick, 'Barack Obama's Decision on Missile Defense', The World Security Network (1 October 2009).

58 In February 2010 the long-term agreement between Russia and Poland on gas deliveries was signed. This was supplemented with visa regime simplification for the residents of the RF Kaliningrad Region, the development of a Belarus-related policy, and aspects of partner cooperation in the framework of the EU Eastern Partnership initiative. See 'Lithuania Hails EU Court Ruling in Spat Over Polish names' (n 45).

59 In Šalčininkai, over 95\% of land has been restituted, and the same is true of the Trakai and Vilnius districts. However, the town of Vilnius is problematic due to miscellaneous business interests; Dambrauskaitè and others (n 46) 137. For an outline of the current problems, see M Narbutt, 'Lietuviu Ir Lenku Brolybès Nebeliko Nè Pèdsako [Lithuanian and Polish Brotherhood Vanished Without a Trace]' Lrytas.lt (29 October 2010).

60 BNS, 'Lietuvos URM Apkaltino Lenkijos Pareigūnus Skelbiant Klaidinga Informacija [Lithuanian Ministry of Foreign Affairs Accuses Polish Officials of Promulgating False Information]' Alfa.lt (21 October 2010).
} 
from school to university level may be obtained in Polish'. ${ }^{61}$ The issue of the Polish minority in Lithuania became prominent on the agenda of the Civic Platform ${ }^{62}$ and the Law and Justice parties in Poland ${ }^{63}$ and continues to be presented as a 'hot topic' by media and politicians in both Member States. ${ }^{64}$

\subsection{Runevič-Vardyn: the final countdown}

Having looked at the politics of Polish-Lithuanian relations, it is worth moving to the legal background of the Runevič-Vardyn dispute. The starting point is Article 14 of the Lithuanian Constitution providing that the state language is Lithuanian, which has priority over any other language. According to a long-standing doctrine of the Lithuanian Constitutional Court, the legal regulation of human rights, including definitions, contents, and implementation, must be regulated only by primary legislation; this also applies to the core rules on spelling names and surnames in Lithuanian passports. ${ }^{65}$ At the moment, such primary legislation does not exist. The Civil Code does state that 'every person shall enjoy the right to a name', ${ }^{66}$ while at the same time making the reservation that the spelling of any name acquired through marriage is to be governed by secondary legislation on civil metrication, ${ }^{67}$ which is to take into account primary legislation on the spelling of names. Unfortunately, the primary legislation of which the Constitution speaks and which is to be the basis for secondary legislation on civil metrication does not exist. ${ }^{68}$ Despite this gap, there are related laws on ID cards ${ }^{69}$ and passports, ${ }^{70}$ as well as

61 DELFI, 'E. Lucasas: Lietuvoje Gera Būti Lenku [E. Lucas: It Is Good to Be Polish in Lithuania]' Delfi.lt (21 February 2011).

62 The ex-Prime Minister Donald Tusk's party, in power (coalition) with the Polish People's Party until October 2015; BBC, 'Poland Re-Elects PM Donald Tusk' BBC News (10 October 2011).

63 The late president Lech Kaczynski's party, where Radosław Sikorski was his greatest rival (Sikorski was the Minister of National Defence (2005-2007) in Jarosław Kaczyński's Cabinet; later the Minister of Foreign Affairs in Donald Tusk's Cabinet and Speaker of the Sejm, the lower chamber of the Polish Parliament).

64 See, inter alia, W Borodzicz-Smolinski and V Jurkonis, 'Lithuania and Poland: Lost in Translation', Europe's World (11 April 2012).

65 Decision of the Constitutional Court of the Republic of Lithuania No KT7-S4/2014 of 27 February 2014 on clarifying certain aspects of the Decision of the Constitutional Court of the Republic of Lithuania of 21 October 1999 concerning the spelling of names and surnames in passports of Lithuanian citizens (TAR, 2014, No 2336), Part III, para 8.

66 Article 2.20(1) of the Lithuanian Civil Code.

67 See Articles 3.31, 3.281 and 3.282 of the Lithuanian Civil Code.

68 Article 8 of the Decree of the Minister of Justice No 1R-160 of 19 May 2006 concerning the confirmation of the civil metrication rules (Žin, 2006, No 65-2415). This article was written when the law was being negotiated in the Seimas (June 2015).

69 Law No IX-577 of 6 November 2001 concerning identity cards (Žin, 2001, No 973417), as amended (Žin, 2008, No 76-3007).

70 Law No IX-590 of 8 November 2001 concerning passports (Žin, 2001, No 99-3524), as amended (Žin, 2008, No 87-3466). 
executive decrees (secondary legislation) on passports ${ }^{71}$ and civil registration rules. ${ }^{72}$ The latter specify that all entries on certificates of civil status must be made in Lithuanian, ${ }^{73}$ and that for Lithuanian citizens the information stated on identity cards and passports must be entered in Lithuanian characters, whereas the names on marriage certificates of non-Lithuanian nationals 'may be entered in accordance with the entries made in the [applicant's] passport ... or in any other equivalent document ${ }^{74}$ issued by that other State.

The relevant current secondary legislation is the Decree of the Supreme Council ${ }^{75}$ concerning the writing of surnames and forenames in passports of Lithuanian citizens. It was scrutinised by the Constitutional Court in $1999,{ }^{76}$ in the light of Articles 18, 22, 29, and $37^{77}$ of the Lithuanian Constitution. The challenge was based on the fact that the names of Lithuanian nationals (both from Lithuanian and other ethnic backgrounds) on their passports were spelt using only the Lithuanian alphabet. The Court referred to the already mentioned Article 14 of the Constitution, which guarantees the constitutional status of the Lithuanian language, ${ }^{78}$ and stated that the Decree of the Supreme Council did not regulate the private life of persons, ${ }^{79}$ concluding that the writing of names in the Lithuanian passports fell outside the domain of private life. Allowing the writing of names in foreign alphabets, according to the Constitutional Court, would not only infringe the constitutional principle of state language embedded in Article 14 of the Constitution, but

\footnotetext{
71 Decree No I1031 of the Lithuanian Supreme Council of 31 January 1991 concerning the writing of surnames and forenames in passports of citizens of the Republic of Lithuania (Žin, 1991, No 5132).

72 Decree No IR294 of the Minister for Justice of 22 July 2008 confirming the civil registration rules (Žin, 2008, No 883541).

73 Para 11 of Decree No IR294.

${ }^{374}$ Paragraph 3 of Decree No I1031.

75 The Supreme Council was a transitional body that exercised sovereignty prior to Lithuania's full independence.

76 Decision of the Constitutional Court of the Republic of Lithuania of 21 October 1999 on the constitutionality of the decision of 31 January 1991 of the Supreme Council concerning the spelling of names and surnames in passports of Lithuanian citizens (Žin, 1999, No 902662).

77 18: commitment to human rights and freedoms, 22: the right to private life, 29: equality, 37: rights of ethnic minorities.

378 Decision of the Constitutional Court_of the Republic of Lithuania of 21 October 1999 on the constitutionality of the decision of 31 January 1991 of the Supreme Council concerning the spelling of names and surnames in passports of Lithuanian citizens (Žin, 1999, No 902662), para 4. See also the Decision No 14/98 of the Constitutional Court of the Republic of Lithuania of 6 November 2009 on the explanation of the Decision of 21 October 1999 (Žin, 2009, No 134-5859), Part III, para 4.

79 Decision No 14/98 of the Constitutional Court of the Republic of Lithuania of 6 November 2009 on the explanation of the Decision of 21 October 1999 (Žin, 2009, No 134-5859), para 6.
} 
also impede the proper functioning of state institutions, which would in turn make it difficult for all citizens to exercise their rights and legal interests. ${ }^{80}$ As the Decree applied to all citizens equally, irrespectively of their ethnic background or other distinguishing factors, it was held to be non-discriminatory and constitutional. ${ }^{81}$ In this way, it seems, the Constitutional Court ruled on the basis of formal equality, without addressing the possible de facto discrimination between Lithuanian nationals of different ethnicities.

In 2004, the same Decree was challenged as infringing the international human rights rules to private life. Michal Kleckovski, an ethnic Pole, who was born on 7 December 1969 in Lithuania, claimed the Lithuanian law contradicted Articles 17, read alone and in conjunction with Articles 2, 26 and 27 of the International Covenant on Civil and Political Rights (ICCPR). ${ }^{82}$ Until the end of the Soviet rule in 1991, his name was recorded officially in Lithuanian and in Russian, but since Lithuania's independence in 1991, the applicant had only been able to use his name as spelt in Lithuanian (even though the Polish pronunciation was preserved). In its defence before the ICCPR, Lithuania pointed out that $\mathrm{Mr}$ Kleckovski's claim was:

manifestly ill-founded because the author's uncle, Tadeus Kleckovski, previously submitted the same matter to the European Court of Human Rights which declared it inadmissible on 31 May 2001 as manifestly ill-founded and not disclosing any appearance of a violation of article 8 of the European Convention on Human Rights (right to privacy), ${ }^{83}$ taken alone or in conjunction with article 14 (principle of non-discrimination in the enjoyment of the Convention rights). ${ }^{84}$

Thus, the ICCPR Commission refused Kleckovski's claim on jurisdictional grounds: minority rights were outside the scope of ICCPR pro-

\footnotetext{
80 ibid, para 7.

81 See F Palermo, 'Judicial Adjudication of Language Rights in Central, Eastern, and SouthEastern Europe: Principles and Criteria' (2011) 2 EDAP. On the concept of substantive equality, see C McCrudden and S Prechal, The Concepts of Equality and Non-discrimination in Europe: A Practical Approach (European Commission/European Network of Legal Experts in the Field of Gender Equality, no date); C Nikolaidis, The Right to Equality in European Human Rights Law: The Quest for Substance in the Jurisprudence of the European Courts (Routledge 2014).

82 Kleckovskiv Lithuania, Comm 1285/2004 (HRC 2007).

83 As Račkauskaitè notes, the European Convention on Human Rights, too, does not cover minority rights; the possibility to extend the scope of Article 8 (the right to private life) for this purpose is quite limited, according to the case law of the European Court of Human Rights (eg Mentzen v Latvia App no 71074/01 (ECHR 7 December 2004)); see Račkauskaitè (n 14) 365.

${ }^{84}$ Kleckouski (n 82) para 4.5.
} 
tection. As the problem remained, ${ }^{85}$ it was no surprise that in $2007 \mathrm{Ms}$ Runevič-Vardyn initiated a case against Lithuanian authorities for their refusal to spell her name on civil registration documents in Polish. This time, similar questions were posed to the Court of Justice.

\subsection{The Runevič-Vardyn case}

Against this political and legal background we shall now proceed with an analysis of the Runevič-Vardyn case. The starting point is a brief overview of the factual background, which is followed by an analysis of the Opinion of Advocate General Jääskinen and the judgment of the Court of Justice.

\subsubsection{Factual background}

The Runevič-Vardyn case was brought before the Court of Justice when a Lithuanian national of Polish origin, who was married to a Polish national and lived in Belgium, requested that her name in her marriage certificate be spelt using the Polish version of the name, Małgorzata Runiewicz-Wardyn. Given that the Lithuanian alphabet did not have the letter 'W', and that Lithuanian laws stipulate that forenames and surnames must be entered in official documents using the spelling and rules of the official language of the country, Ms Runevič-Vardyn's request was rejected. More particularly, in all birth certificates issued since her birth, Ms Runevič-Vardyn's name had been spelt in accordance with a Lithuanian custom, in this form: 'Malgožata Runevič'. She, however, argued that the original birth certificate was written in the Cyrillic alphabet and referred to her Polish ethnicity, as did her passport, issued in 2002. Moreover, she also acquired a birth certificate from the Polish authorities, bearing the Polish spelling of the name, in 2006.

\footnotetext{
85 Runevič-Vardyn was not the first such case in Lithuanian courts, where changing of one's name after marriage became problematic. On 30 June 2011, the First District Court of the City of Vilnius refused to admit a case $J V$ involving a Lithuanian national, who married an Austrian national and requested her marriage certificate and passport to contain the letter 'W' in her name. The refusal was appealed at Vilnius County Court and later at Vilnius Court of Appeal and the Supreme Court of Lithuania, both of which did not uphold the claim. See the decision of Vilnius Court of Appeal of 8 November 2013 (Case No 2A-1304232/2012) and the decision of the Supreme Court of Lithuania of 17 July 2013 (Case No 3K-3-392/2013). The European Foundation of Human Rights (EFHR) estimates that more than $16 \%$ of marriages registered in Lithuania are mixed (one spouse is a foreign national); there was also an increase from $1 \%$ to $16 \%$ of children born outside Lithuanian territory from 2001 to 2011. For personal accounts in mixed marriage families about the difficulties caused by the current rules, see the submissions to the legislative deliberations to the Seimas Committee of Legal Affairs from Migle Vantens and Bart Pauwels \& Ernesta Pauvels; see Lietuvos Respublikos Seimo teisès ir teisètvarkos komitetas. Pagrindinio komiteto išvados dèl Lietuvos Respublikos vardu ir pavardžiu rašymo dokumentuose îstatymo projekto (Nr XIIP-1675) 2015 m gegužès 6 d Nr 102-P-17 [Committee on Legal Affairs, Conclusions of the Main Committee regarding the Draft Law No XIIP-1653 on writing names and surnames in official documents (5 May 2015, 102-P-17)].
} 
In 2007, Ms Runevič married Mr Lukasz Pawel Wardyn in Lithuania. The Lithuanian marriage certificate spelt the husband's name with a 'W', but the wife's name was spelt with a ' $V$ '. When the claimant requested the certificate be corrected in order to show the Polish spelling, she was told that this would be impossible.

Ms Runevič-Vardyn initiated legal proceedings against the decision, and the case was eventually referred by the Lithuanian court to the Court of Justice under Article 267 TFEU. The couple claimed that, as their names stood, they were experiencing practical difficulties ('serious inconveniences') in Belgium when receiving post on behalf of each other, arranging common banking services, registering for academic conferences, reserving flights, booking hotels, entering into legal contracts, or performing any other action on each other's behalf, such as registering their children for school. ${ }^{86}$ The first two questions in the case related to the interpretation of Directive 2000/43/EC, ${ }^{87}$ and asked whether the Lithuanian practice was indirectly discriminatory against nationals of other Member States whose names were written without their diacritical marks, and, more generally, whether the rule for civil documents to be written only in the official language was discriminatory. Two further questions concerned the compatibility of the Lithuanian rules on spelling of names on IDs with Articles 21(1) and 18(1) TFEU.

\subsubsection{Opinion of Advocate General Jääskinen}

Having stated the facts, AG Jääskinen promptly referred to the curious historical and political context of the case, including the interwar conflict around the south-eastern part of Lithuania. This reference was enough to distinguish Runevič-Vardyn and Sayn-Wittgenstein from previous cases on the spelling of names. These two cases were not just about the right to one's name in the context of the exercise of fundamental freedoms; they concerned potentially sensitive issues, or, as rightly put by AG Jääskinen, 'keen emotions'. ${ }^{88}$ Both cases touch upon the issues central to national constitutional identity: language and the equality of all individuals. The Advocate General unsurprisingly repeated the usual maxim: the Member States have jurisdiction over matters of civil law, but they should respect EU law when exercising that discretion. ${ }^{89}$ Given that Lithuania joined the European Union relatively recently, it could not have been expected to have amended its entire legal system, includ-

\footnotetext{
86 ibid.

87 Directive 2000/43/EC on equal treatment irrespective of racial or ethnic origin [2000] OJ L303/16.

88 Opinion of AG Jääskinen, para 5.

89 Case C-135/08 Janko Rottman v Freistaat Bayern ECLI:EU:C:2010:104.
} 
ing the documents which were issued prior to joining the EU. Moreover, the Advocate General addressed the potential applicability of Directive 2000/43/EC and found that its scope extended to areas where the EU has competences, but civil matters were not included in these areas. ${ }^{90}$ Consequently, notwithstanding the claimants' views that the discrepancy in spelling may prevent them from enjoying full access to goods and services in the Union, the Advocate General found no substantive evidence of such a risk. He ascertained that the matter in the main proceedings was one of different spelling, which, nonetheless, allowed for a connection to be drawn between the two versions of the name.

Further, with regard to the applicability of the non-discrimination provisions, AG Jääskinen established that, in terms of Ms RunevičVardyn's birth certificate, there was nothing to suggest she had been discriminated against, as she was a national of the Member State that issued her document. In other words, this was a wholly internal situation. Her husband, on the other hand, could have suffered discrimination because of the refusal to use Polish diacritical marks in his name on the Lithuanian marriage certificate. Regarding his inability to pass the Polish name onto his legal spouse, AG Jääskinen regarded this argument as incompatible with the general principle of equality between the sexes under EU law, but he agreed that in similar situations Lithuanian nationals of Lithuanian ethnicity would be more favourably treated, as their names would be clearly compatible with the Lithuanian language and its spelling rules. On the freedom of movement, AG Jääskinen argued that Ms Runevič-Vardyn's claim to barriers to free movement was unsubstantiated because her birth certificates were issued in her country of origin, while Mr Wardyn's rights to free movement had not been restricted, as the omission of diacritical marks was a common occurrence, practised for reasons of simplicity.

The Opinion was thus far rather unsurprising and predictable. When AG Jääskinen reached the justification part, he rightly acknowledged that Member States had the right to adopt laws with a view to protecting their languages as a matter of public policy. However, he went on to say that the Lithuanian measure did not pass the proportionality test: Lithuania's efforts to amend its laws governing the spelling of names and surnames, which will be the focus of Part 3.6 of this paper, were seen as clear evidence that there were less restrictive measures than the one adopted. Furthermore, although the diacritical marks, or absence thereof, were not regarded as an obstacle to free movement, it was argued that the situation was different when letters were omitted just because

90 As per Article 3, Directive 2000/43/EC applies to employment related situations. 
they did not exist in an alphabet. In the latter instance, the Lithuanian argument seemed inconsistent: the letter W was allowed in Mr Wardyn's name, but the same treatment was not afforded to his wife. Therefore, it is difficult to see how the Lithuanian language was in danger.

\subsubsection{Judgment of the Court of Justice}

The Court grouped the first two questions, which dealt with the applicability of Directive 2000/43/EC, and reached the same conclusion as the Advocate General, using a similar rationale. It, too, mentioned the travaux préparatoires, which were clear in their admission that the Directive did not apply to civil law cases rationae materiae. ${ }^{91}$ Thus, Ms Runevič-Vardyn could not rely on this Directive. Similarly, the remaining questions were addressed together, and the Court, much as the Advocate General did, divided the arising issues into three distinct groups:

1. The first concerned Ms Runevič-Vardyn's claim to have her name spelt in the Polish manner in her marriage and birth certificates (Runiewicz);

2. The second was the request of both claimants that Mr Wardyn's surname, 'joined to the maiden name of the first applicant', be spelt using the Polish spelling (Runiewicz-Wardyn);

3. The third was Mr Wardyn's request that his surname be entered in the marriage certificate in the original, Polish spelling with diacritical marks (Łukasz Paweł Wardyn). ${ }^{92}$

The Court's judgment did not differ much from the AG's Opinion. With regard to the balance between protecting Lithuania's right to its linguistic tradition and the need to ensure that the measure it had taken was a proportional intervention in the right to personal identity of EU citizens, the Court's reasoning is interesting and noteworthy in its own right, because it wondered why Lithuania would agree to use the letter 'W' for Mr Wardyn (a Polish national), but would refuse to do the same for Mrs Vardyn (a Lithuanian national of Polish ethnicity) when there were clearly no technical or other barriers. The Court acknowledged the need to protect the Union's rich heritage, but repeated that such efforts should not affect the rights of the Union's citizens disproportionately. Nevertheless, it left for the national court to apply the proportionality test. ${ }^{93}$ Thus, as far as the first issue identified above was concerned, although the Court confirmed that there

\footnotetext{
91 Para 46.

92 Para 50.

93 Para 91.3
} 
was evidence of a breach of free movement rules, Lithuania could refuse to amend the spelling subject to a proportionality test.

As for the second claim, the Court held that the decision on using the same spelling for both spouses would depend upon the existence of a serious inconvenience caused by the use of two distinct spellings. According to the Court, the responsibility for reaching a decision whether the inconvenience was serious rested with the national court. ${ }^{94}$

With regard to the third issue, the Court held that the decision of Lithuania to refuse to amend the marriage certificate, so it was compatible with the original spelling that included diacritical marks, was not a breach of free movement rights, because such marks are often omitted owing to the design of technical equipment.

Therefore, it is clear that the Court followed the reasoning of the Advocate General and endeavoured to apply the relevant provisions considering their aim, but also to respect the law of Lithuania, by ruling that the national court should apply the proportionality test to discern whether the national measure is too strict a practice. The Advocate General was admittedly rather more explicit when he opined that there were other measures, which were less harsh than the Lithuanian one, ${ }^{95}$ but the Court followed a more timid approach. The final section of this part will endeavour to analyse the two distinct views and the lessons learnt, before the analysis moves on to Lithuanian attempts to amend the national laws concerning names.

\subsection{Application of the CJEU's judgment by the referring court and the exportability of the judgment to relations between the Member States}

Having looked in detail at what happened in the Luxembourg courtroom, it is now fitting to analyse how the referring court in Lithuania applied the judgment of the Court of Justice. On 18 August 2011, the First District Court of the City of Vilnius ${ }^{96}$ refused the request of the applicants to amend their surnames and forenames as they appeared on the certificates of civil status. ${ }^{97}$ While it acknowledged that the different spelling of Ms Runevič-Vardyn's name did cause inconveniences related

94 Para 78.

95 Para 84.

96 Vilniaus miesto 1 apylinkès teismas; the court of first instance.

97 First District Court of the City of Vilnius Press Release, 'Teismas Nusprendè, Kad Pavardès Dokumentuose Turi Būti Rašomos Lietuviškais Rašmenimis [The Court Decided That Names in Official Documents Must Be Spelt in Lithuanian Letters]' (18 August 2011) <http://www2.lat.1t/portal/start.asp?act=news\&Tema=49\&str=48028> accessed 14 September 2015. 
to the proof of identity in her daily life, it stressed that this situation was the result of the conscious behaviour of the applicant herself. Even though Ms Runevič-Vardyn had a Lithuanian birth certificate (where her name was spelt in Lithuanian characters), while residing in Poland, she changed her identity-certifying documents into ones that codify her name in the Polish alphabet in order to introduce herself to the academic community in Poland. ${ }^{98}$ Having finished Lithuanian secondary school, Ms Runevič-Vardyn then moved to Poland to become a well-established academic. ${ }^{99}$ While she did experience objective practical difficulties living in the EU after marriage, according to the Lithuanian court these difficulties could easily be solved by providing the relevant institutions with supplementary documents confirming personal identity: the Lithuanian marriage certificate that is translated into the relevant language. ${ }^{100}$ Relying on the above, the national court held that the applicants experienced only 'regular' personal/domestic inconveniences because of the current spelling of their names. These were not 'serious inconveniences' at the administrative, professional, and private levels that could render national law inapplicable. ${ }^{101}$ Therefore, according to First District Court of the City of Vilnius, the national law on the spelling and writing of names of Lithuanian citizens was applicable to Ms Runevič-Vardyn and did not contradict EU law.

The outcome at the Lithuanian court is not surprising, given the discretion awarded by CJEU, as well as ECtHR, jurisprudence. Having in mind the expected accession of the EU to the ECHR, ${ }^{102}$ it is quite possible that the CJEU might have been influenced indirectly ${ }^{103}$ by the ECtHR judgment in Metzen $v$ Latvia, ${ }^{104}$ which left wide discretion for national courts and other institutions on how to spell the names of ethnic minority Latvian nationals. In Lithuania, the start of the litigation did not prevent debates on necessary legislative reform; thus, the Runevič-Vardyn judg-

\footnotetext{
98 ibid.

99 TIGER, 'Dr. Malgorzata Runiewicz-Wardyn' (no date) <http:/ /www.tiger.edu.pl/english/ onas/runiewicz/cv.htm> accessed 22 August 2014.

100 First District Court of the City of Vilnius Press Release (n 97).

101 See para 76 of the Runevič-Vardyn case.

102 Article 6(2) TEU.

${ }^{103}$ Interestingly, this case was mentioned neither in the AG's Opinion nor in the CJEU's judgment.

104 As noted earlier, according to Article 53(2) CFR, the Charter rights corresponding to the ECHR (ie the right to a private life) must be interpreted in the light of ECtHR jurisprudence. As far as the latter is concerned, the case of Mentzen $v$ Latvia is of relevance. The ECtHR awarded a large margin of appreciation for the national authorities in a post-communist state (Latvia) and held that the breach of the right to private life under Article 8 ECHR was proportional in order to protect the state language, which is a constitutional national value (in the same way as state territory, organisational structure, or a national flag is).
} 
ment continued to be explored while discussing proposals for revision of the law on names in the Seimas during 2007-2015. At the same time, the lawyers representing Mr Wardyn and Ms Runevič-Vardyn were continuing to pursue their case via Lithuanian courts. As the State Commission of the Lithuanian Language has refused to adopt a position that differs from the previous rulings of the Constitutional Court, another claim by Ms Runevič-Vardyn is currently pending before the same court that is the sole interpreter of the Lithuanian Constitution. At the moment, it seems that this is the only hope that many Lithuanian ethnic Poles have. ${ }^{105}$

\subsection{Runevič-Vardyn and legislative reform in Lithuania: what for the future?}

As the judicial route was not successful, what about progressive legislative reform? What would it mean for Polish-Lithuanian relations and European integration if such reform does not take place? These are the questions to which we turn next.

Given the complicated history, there is no surprise that debates on the new Lithuanian law on the spelling of names have been continuing since 2007. Naturally, there are two competing views. The first is to give priority to the Lithuanian language (the status quo camp), while the second aims for a more inclusive option (the liberal camp). The latter, reflected in the opinion of Šimašius, ${ }^{106}$ observes that the writing of one's name and surname in the original language is a human right, which must be ensured as long as it is in line with public order and does not add any additional cost to taxpayers. ${ }^{107}$ Šimašius believes that, despite the CJEU's ruling in favour of the existing law, there is a need to introduce a legislative change. ${ }^{108} \mathrm{He}$ makes a reference to a pre-WWII Lithuania, where foreign alphabets were commonly used in all newspapers, ${ }^{109}$ even though the 1922 and 1938 Lithuanian Constitutions, just like the current Constitution, protected the Lithuanian language as the state

\footnotetext{
${ }^{105}$ BNS, 'Lietuviu Kalbos Komisija: Už Užsieniečių Ištekejjusioms Moterims Reikètú Leisti Pase Rašyti Originalias Pavardes [The State Commission of the Lithuanian Language: Women Married to Foreign Nationals Should Be Allowed Original Surnames in Their Passports]' Delfi.lt (20 March 2013); ELTA, 'Ieškant Sprendimo Dėl Nelietuvišku Pavardžiu Rašybos - Dar Vienas šnipštas [Looking for Solutions on Writing Non-Lithuanian Surnames: One More Dead End]' Delfi.lt (30 October 2013).

106 The Minister of Justice of Lithuania 2008-2012.

107 Granickas (n 20).

108 BNS, 'R Šimašius: Reikia Nuleisti Garą Diskusijose Dėl Nelietuvišku Raidžiu [We Need to Let Off Steam in Discussions on Non-Lithuanian Letters]' Zebra.lt (24 November 2011). 109 ibid.
} 
language. ${ }^{110}$ Moreover, Lapinskas ${ }^{111}$ points to the official, contemporary Lithuanian grammar rules, ${ }^{112}$ which allow the use of the letters $\mathrm{Q}, \mathrm{W}, \mathrm{X}$ (and even $\ddot{A}, \mathrm{Ö}, \ddot{U}, \AA$ ) in non-Lithuanian words, especially in a person's name. Palermo, too, observes the shortcomings of the Lithuanian law and the unwillingness of the Lithuanian Constitutional Court in the past to protect the human right to a name. In his view, the Constitutional Court adopted a formal reading of equality, ${ }^{113}$ leaving minority rights 'remarkably limited'. ${ }^{114}$

Next to the liberal human-rights-based argument, Poland has often stated that, in the spirit of the TFRGNC, ethnic Poles in Lithuania should be allowed to spell their names in the Polish alphabet. ${ }^{115}$ Lithuania, on the other hand, has always relied on the literal interpretation of the TFRGNC and pointed out that in some of the countries where the ethnic Polish population was much larger than in Lithuania (Germany, France, the UK, the Czech Republic, the US, Brazil, and Ukraine) none of the ethnic minorities were allowed to have their names in the original language in official documents. ${ }^{116}$ However, one could say that in a democratic state based on the rule of law, the incentive for human rights protection should be the rights themselves, not the fact that another EU Member State requires reciprocity under bilateral treaties. ${ }^{117}$

For the above reasons, while the national court awaited the judgment from the CJEU in Runevič-Vardyn, there were initiatives for legal changes emerging in the Lithuanian parliament (the Seimas) and the Constitutional Court. In 2009, ten years after the Constitutional Court's Decision that upheld Lithuanian rules on the spelling of citizens' names as constitutional, ${ }^{118}$ the Seimas again turned to the Constitutional Court,

\footnotetext{
${ }^{110}$ Decision of the Constitutional Court of the Republic of Lithuania No KT7-S4/2014 of 27 February 2014 on clarifying certain aspects of the Decision of the Constitutional Court of the Republic of Lithuania of 21 October 1999 concerning the spelling of names and surnames in passports of Lithuanian citizens (TAR, 2014, No 2336), Part III, para 6.4.

${ }^{111}$ A Lapinskas, 'Dar Vienas Raidès W žygis i Lietuvišką Rašyba [One More Quest by the Letter W into Lithuanian Spelling]' [2012] Delfi.lt.

${ }^{112}$ V Ambrazas (ed), Dabartinés Lietuviu Kalbos Gramatika [Contemporary Lithuanian Grammar] (Mokslo ir enciklopediju leidykla 1994).

${ }^{113}$ See the Constitutional Court's judgment discussed above.

${ }_{114}$ Palermo (n 81) 18.

${ }^{115}$ Dambrauskaite and others (n 46) 135.

116 Granickas (n 20).

${ }^{117}$ E Lucas, 'Dialogue of the Deaf Between Vilnius and Warsaw', The Economist (London, 10 February 2012).

${ }^{118}$ Decision of the Constitutional Court of the Republic of Lithuania of 21 October 1999 on the constitutionality of the decision of 31 January 1991 of the Supreme Council concerning the spelling of names and surnames in passports of Lithuanian citizens (Žin, 1999, No 902662).
} 
asking it to explain in more detail paragraphs $4^{119}$ and $7^{120}$ of the above Decision. In particular, whether it was possible on a Lithuanian passport to state a person's name using non-Lithuanian characters, after having stated the same name in Lithuanian first, in situations where the person in question requests so and provides Lithuanian authorities with the personal identification documents issued abroad. The Constitutional Court ruled that, as long as the general rule was observed - that all names must be spelt in the Lithuanian alphabet ${ }^{121}$ - it was possible for a legislator to exercise its discretion to allow the original name to be written in any other parts of the document (passport), as long as the name was written in Latin characters. ${ }^{122}$ However, the Constitutional Court stressed, the name spelt in a foreign language did not amount to a record of personal identity in the state's official language, ${ }^{123}$ despite the calls for a different approach by Lithuanian citizens of the Polish minority. ${ }^{124}$

As already mentioned, besides the constitutional law jurisprudence, there were also legislative initiatives. In 2007, the Lithuanian Government made a proposal to the Seimas to revise the law, in order to allow 'for names in passports, personal IDs, and other documents to be spelled in all Latin-based characters ${ }^{125}$... without any additional write-ups in Lithuanian'. ${ }^{126}$ This was followed by four later legislative proposals, all of which are summarised in the table below.

\footnotetext{
119 'In Lithuanian passports, a person's name and surname must be spelt in the state language.'

120 'Allowing the writing of names in foreign alphabets would not only infringe the constitutional principle of state language, but also impede upon the proper functioning of state institutions.'

${ }^{121}$ Decision No 14/98 of the Constitutional Court of the Republic of Lithuania of 6 November 2009 on the explanation of Decision of 21 October 1999 (Žin, 2009, No 134-5859), Part III, para 6.

122 Decision No 14/98, para 7.

123 Decision No 14/98, para 8.

${ }^{124}$ Palermo (n 81) 18.

125 The Russian-speaking minority would not have names in Cyrillic.

126 Palermo (n 81) 18.
} 
Table A: Legislative proposals to reform the law on the spelling of names 2007-2012

\begin{tabular}{|c|c|c|c|c|c|}
\hline & \begin{tabular}{|l|}
$\mathrm{XP}-689 A(2)$ \\
08-06-2007
\end{tabular} & \begin{tabular}{|l|} 
XIP-567(3) \\
09-09-2009
\end{tabular} & \begin{tabular}{|l|} 
XIP-1668 \\
$19-01-2010$
\end{tabular} & \begin{tabular}{|l|} 
XIP-1644(2) \\
29-03-2010
\end{tabular} & \begin{tabular}{|l|} 
XIP-4379(3) \\
$15-06-2012$
\end{tabular} \\
\hline Proposer & $\begin{array}{l}\text { The Govern- } \\
\text { ment }\end{array}$ & $\begin{array}{l}\text { Česlovas V } \\
\text { Stankevičius } \\
\text { (Conserva- } \\
\text { tive: } \\
\text { Homeland } \\
\text { Union) }\end{array}$ & $\begin{array}{l}\text { Gintaras } \\
\text { Songaila } \\
\text { (Conserva- } \\
\text { tive: } \\
\text { Homeland } \\
\text { Union) }\end{array}$ & \begin{tabular}{|l|} 
Andrius Ku- \\
bilius \\
(Conservative: \\
Homeland \\
Union)
\end{tabular} & \begin{tabular}{|l|} 
Česlovas V \\
Stankevičius \\
(Conservative: \\
Homeland \\
Union)
\end{tabular} \\
\hline ats & $\begin{array}{l}\text { Allows using } \\
\text { both Lithu- } \\
\text { anian and } \\
\text { other char- } \\
\text { acters of } \\
\text { Latin origin } \\
\text { in personal } \\
\text { names. } \\
\text { Article } 9(5) \\
\text { states that } \\
\text { the priority } \\
\text { is given to } \\
\text { the spelling } \\
\text { in the iden- } \\
\text { tity docu- } \\
\text { ment issued } \\
\text { by the state } \\
\text { of which a } \\
\text { person is } \\
\text { the national. } \\
\text { According to } \\
\text { Article } 7(3), \\
\text { if a person } \\
\text { changes } \\
\text { their name } \\
\text { to the name } \\
\text { of their } \\
\text { spouse, the } \\
\text { name will } \\
\text { be recorded } \\
\text { in the same } \\
\text { way as the } \\
\text { name of the } \\
\text { spouse. }\end{array}$ & $\begin{array}{l}\text { Allows using } \\
\text { both Lithu- } \\
\text { anian and } \\
\text { other char- } \\
\text { acters of } \\
\text { Latin origin } \\
\text { in personal } \\
\text { names. } \\
\text { Article 4(1)(1) } \\
\text { allows names } \\
\text { of foreign } \\
\text { nationals in } \\
\text { the Latin al- } \\
\text { phabet to be } \\
\text { copied as in } \\
\text { original iden- } \\
\text { tity docu- } \\
\text { ments when } \\
\text { the name is } \\
\text { transcribed } \\
\text { in Lithuanian } \\
\text { identity } \\
\text { documents. } \\
\text { Article } 5 \text { al- } \\
\text { lows Lithu- } \\
\text { anians, who } \\
\text { marry foreign } \\
\text { nationals, } \\
\text { to take the } \\
\text { name of the } \\
\text { spouse in } \\
\text { full, as long } \\
\text { as that name } \\
\text { is in Latin } \\
\text { characters. }\end{array}$ & $\begin{array}{l}\text { Articles } \\
4 \text { and } 5 \\
\text { include a } \\
\text { possibility } \\
\text { for foreign } \\
\text { names to be } \\
\text { written in } \\
\text { Lithuanian } \\
\text { passports in } \\
\text { Latin let- } \\
\text { ters only, as } \\
\text { long as the } \\
\text { 'official' name } \\
\text { is written in } \\
\text { Lithuanian. } \\
\text { However, } \\
\text { Article } 6 \\
\text { proposes to } \\
\text { take a fee } \\
\text { for such a } \\
\text { service, in or- } \\
\text { der to cover } \\
\text { administra- } \\
\text { tive expenses } \\
\text { related to } \\
\text { such a tran- } \\
\text { scription. } \\
\text { Charging of } \\
\text { the fee may } \\
\text { be deemed } \\
\text { to constitute } \\
\text { indirect dis- } \\
\text { crimination } \\
\text { under the } \\
\text { grounds of } \\
\text { ethnic origin. }\end{array}$ & $\begin{array}{l}\text { Article 3(2): } \\
\text { names of } \\
\text { Lithuanian } \\
\text { citizens can } \\
\text { be written in } \\
\text { foreign (Latin) } \\
\text { characters, if } \\
\text { such a spell- } \\
\text { ing exists in } \\
\text { their identity } \\
\text { documents. } \\
\text { Article 3(3): } \\
\text { names of } \\
\text { foreign citi- } \\
\text { zens can be } \\
\text { written in } \\
\text { foreign (Latin) } \\
\text { characters, } \\
\text { according to } \\
\text { the existent } \\
\text { spelling in } \\
\text { their identity } \\
\text { documents. } \\
\text { If there is } \\
\text { no identity } \\
\text { document, } \\
\text { the name will } \\
\text { be written in } \\
\text { Lithuanian } \\
\text { letters accord- } \\
\text { ing to pro- } \\
\text { nunciation. }\end{array}$ & $\begin{array}{l}\text { Article } 4 \text { does } \\
\text { not differenti- } \\
\text { ate between } \\
\text { Lithuanian } \\
\text { citizens and } \\
\text { other citizens: } \\
\text { 'any person', } \\
\text { who provides } \\
\text { an origi- } \\
\text { nal identity } \\
\text { document, } \\
\text { is entitled to } \\
\text { a change of } \\
\text { their name. } \\
\text { Article } 5 \text { con- } \\
\text { tains rules on } \\
\text { writing the } \\
\text { surnames of } \\
\text { Lithuanian } \\
\text { citizens who } \\
\text { marry foreign } \\
\text { citizens and } \\
\text { of children } \\
\text { born in such } \\
\text { mixed fami- } \\
\text { lies. These } \\
\text { rules are } \\
\text { quite flex- } \\
\text { ible, allowing } \\
\text { either the } \\
\text { mixed, Lithu- } \\
\text { anian, or } \\
\text { non-Lithuani- } \\
\text { an surnames } \\
\text { spelt in } \\
\text { Latin letters, } \\
\text { depending on } \\
\text { the spelling } \\
\text { in the identity } \\
\text { documents. }\end{array}$ \\
\hline Outc & $\begin{array}{l}\text { Withdrawn: } \\
\text { 14-01-2010 }\end{array}$ & $\begin{array}{l}\text { Withdrawn: } \\
\text { 21-11-2009 }\end{array}$ & Defunct. & $\begin{array}{l}\text { Rejected: } \\
\text { 08-04-2010 }\end{array}$ & Defunct. \\
\hline
\end{tabular}


Lithuanian academic commentary analysing the above proposals is very scarce, ${ }^{127}$ which illustrates a lack of informed intellectual debate not only in state institutions (courts, the Seimas) but also in public discourse. In mainstream media, some points have been made by Egidijus Küris, the current Lithuanian judge at the ECtHR. He argued that Songaila's and Kubilius's bills were not appropriately prepared and scrutinised in the sitting of the Seimas on 8 April 2010; neither was an attempt made to discuss the provisions before a vote was taken on whether to adopt or reject the proposals, nor were there any further discussions about redrafting the proposals. ${ }^{128}$ The proposal by Kubilius would have allowed for any names registered in Lithuania to be spelt in any letters of the Latin alphabet, whereas Songaila proposed non-Lithuanian names to be written in a special section of Lithuanian passports, which would not be equal to the 'official' Lithuanian spelling in the main section of the passport. The latter option of the spelling of names has been implemented in Latvia. However, Latvia is the only EU Member State that has such a regulation, and it has attracted criticism from the United Nations Human Rights Committee. ${ }^{129}$ According to Kūris, Songaila's proposal would not be a satisfying solution, as it would not change the current status quo, where one's identity is divided between 'private-self' and 'publicself', meaning that the current legislative vacuum vis-à-vis writing names in Lithuania 'undermin[es] an ability to choose a language [and] de facto leads to the deprivation of a possibility of being yourself'. ${ }^{130}$ Besides, this proposal does not reflect the changed societal and political situation in contemporary Europe, where the liberal ideology coupled with the protection of human rights resulted in a definitive shift of the default position on the states' engagement with their societies: tolerance and respect came to replace aggressive social constructivism'. ${ }^{131}$

Kūris seems to be more positive towards Kubilius's proposal, which, even though contradictory to the Constitution, allowed for conditions of the materialisation of an individual freedom to decide how $\mathrm{s} /$ he wants his/her name to be spelt in a Lithuanian passport. In the words of Kūris, this proposal 'would have meant the possibility to belong to the Lithuani-

\footnotetext{
${ }_{127}$ There is some literature in the field of Lithuanian language studies, eg P Kniūkšta, Tarp Gramatikos Ir Politikos [In Between Grammar and Politics] (Lietuviu kalbos institutas 2013). However, legal analysis of the legislative proposals is non-existent, except for some thoughts in E Kūris, 'Abècèlès Nelaisvejje [Detained by the Alphabet]' Delfi.lt (25 February 2013).

${ }^{128}$ Kūris (n 127).

129 In Raihman v Latvia, Comm 1621/2007 (HRC 2010), the UNHRC declared a violation of Article 17 of the International Covenant on Civil and Political Rights.

${ }^{130}$ Kochenov and others (n 1) 175.

131 ibid.
} 
an civic nation independently of one's ethnic origin'. ${ }^{132}$ This view is closely linked to Penot's analysis stemming from the CJEU's 'names cases' that 'European citizenship is ... not about creating a European identity, but about protecting the particular identity of the migrant'; 133 it is about 'protecting and encouraging dual (more generally, multiple) memberships, one defined by nationality and the other one by residence'. ${ }^{134}$

After the Lithuanian parliamentary elections in 2012, the newly formed government committed to resolving the issue of the spelling of names. Point 246 under the 'Ethnic Minorities' title of the Government's Programme for 2014-16 135 outlined pledges to prepare a legislative proposal for the Law on Ethnic Minorities; to create a special Government Department to represent ethnic minorities; and to resolve the questions of writing names and surnames in identification documents and of writing street and town names in minority areas. According to the Programme, all legislation was to be drafted taking into account the provisions of the CoE Framework Convention for the Protection of National Minorities (FCNM), discussed earlier in this article.

As a result of the Programme, there were two legislative proposals submitted to the Seimas. The first was registered on 1 April 2014, a day before the Lithuanian Prime Minister Algirdas Butkevičius's visit to the then Polish Prime Minister Donald Tusk, where the latter expressed hope that the issue would be resolved in time to mark the $20^{\text {th }}$ anniversary of the signing of the Treaty on Friendly Relations and Good Neighbourly Cooperation. ${ }^{136}$ This proposal aimed to allow any Latin characters to be used on the main page of Lithuanian passports (the liberal camp). ${ }^{137}$ The second proposal that came before the Seimas on 4 April 2014 was less ambitious: it allowed names with foreign letters to be written on a separate, 'non-official' passport page (the status quo camp). ${ }^{138}$ Thus, it seems,

\footnotetext{
132 Kūris (n 127).

${ }^{133}$ AI Penot, 'The Transnational Character of Union Citizenship' in M Dougan and NN Shuibhne (eds), Empowerment and Disempowerment of the European Citizen (Hart 2012) 26.

134 ibid 34.

${ }^{135}$ Lietuvos Respublikos Seimo 2012 m. gruodžio 13 d. nutarimas Nr. XII-51 "Dèl 3lietuvos respublikos vyriausybės programos" (Žin, 2012, No 149-7630).

136 ELTA, 'Lenkijos Premjeras Reikalauja A Butkevičiaus Spręsti Lenku Problemas Lietuvoje [The Polish Prime Minister Demands A Butkevicius to Solve Polish Problems in Lithuania]' Delfi.lt (2 April 2014).

${ }^{137}$ XIIP-1653, put forward by two members of the Social Democratic Party of Lithuania, Gediminas Kirkilas and Irena Šiaulienè.

${ }^{138}$ XIIP-1675, authored by the members of Homeland Union - Lithuanian Christian Democrats Valentinas Stundys and Rytas Kupčinskas, seemed to have higher political consensus: it was put forward by all Seimas fractions, with the exception of one political party - the Electoral Action of Poles in Lithuania. BNS, 'Originally-Spelled Name on Separate Passport Page "No Solution", TheLithuaniaTribune.com (12 April 2014).
} 
in 2014 the Lithuanian Parliament was, in the words of Robert Frost, between two roads diverging in a yellow wood: ${ }^{139}$ the very same roads that had been trodden on in the legislative proposals of Songaila and Kubilius of 2009 .

During the mentioned state meeting, Butkevičius gave his word to Mr Tusk that the relevant legislation would be passed by May 2014. However, given the two competing proposals and the 2014 European Parliament elections, the debate in the Seimas was postponed until June, ${ }^{140}$ leaving the empty diplomatic promise as an April Fool's legacy, lasting well into summer 2015. It is now clear that the Prime Minister underestimated how long such a sensitive issue would take to legislate upon.

The aim of the legislative initiatives this time - as compared to the 2007-2012 proposals - was not only to agree on the primary legislation, but also to confirm secondary rules that would have to be approved by the Government. The two legislative proposals seem to have generated a wide and open debate, both in the Seimas and in public discourse, which is a positive development. As the deliberations on the status quo camp proposal had been suspended on 6 May 2015, ${ }^{141}$ the focus in May and June 2015 was on the liberal proposal. Despite this, it is still difficult to predict how much the original text will be amended until it passes in the Seimas. Whether the end result will represent proportionately the changed Lithuanian society since 1991 is another question, as is indeed whether Poland - and in particular the Lithuanian Polish ethnic minority - will be entirely happy with the result embedded in the final text.

\section{The right to a name in the CJEU's case law: the aftermath of Runevič-Vardyn}

\subsection{Introduction}

Having looked at the idiosyncrasies of the political and legal context of the case, as well as the case of Runevič-Vardyn itself, we now take a more holistic approach and place this analysis against the previous jurisprudence of the Court discussed earlier in this article. As a first step, we shall endeavour to explore two pathways the Court of Justice could have followed: EU citizenship and fundamental rights. This will lead us

\footnotetext{
${ }^{139}$ R Frost, 'The Road Not Taken' in Mountain Interval (Henry Holt and Company 1920).

${ }^{140}$ BNS, 'Pavardžiu Rašybos Klausimą Valdantieji Nutarè Atidėti Iki Birželio [The Question of Name Writing Has Been Postponed Until June]' KaunoDiena.lt (23 April 2014).

${ }^{141}$ Lietuvos Respublikos Seimo teisès ir teisètvarkos komitetas. Pagrindinio komiteto išvados dèl Lietuvos Respublikos vardu ir pavardžiu rašymo dokumentuose istatymo projekto (Nr. XIIP-1675) 2015 m. gegužès 6 d. Nr. 102-P-17. [Committee on Legal Affairs, Conclusions of the Main Committee regarding the Draft Law No XIIP-1653 on writing names and surnames in official documents (5 May 2015, 102-P-17)].
} 
to evaluate this line of jurisprudence through the lens of well-established discourse on European integration and national identities.

\subsection{EU citizenship or fundamental rights?}

The Court's approach to individuals' names has demonstrated elements of coherence, or at least a tendency towards judicial precedent: Sayn-Wittgenstein made references to Garcia Avello and to Grunkin and Paul, while the latter made reference to Garcia Avello and to Konstantinidis. This is to be expected, as the Court tends to refer to past case law to establish legitimate expectations and formulate a convincing and sound argument, ${ }^{142}$ although the extent to which this happens convincingly has been questioned. ${ }^{143}$ There are a few leitmotifs running through all these cases, although, as will be shown, they do not necessarily consolidate the Court's modus operandi for the protection of the right to a name in EU law.

The first leitmotif is the inclusion of EU citizenship in the rationale as the main driver of the judicial reasoning (excluding, of course, Konstantinidis which was decided before the adoption of the Treaty of Maastricht). This inclusion was arguably a pragmatic choice, given the combination of the questions asked by the referring courts (ie the interpretation of the citizenship provisions), and the fact that some of the cases concerned the rights of minors, where EU citizenship could be the only source of independent rights. ${ }^{144}$ Pragmatism notwithstanding, this leitmotif is loyal to the Court's teleological and functionalist approach, and indicative of a clear move towards citizenship rhetoric even in cases such as Sayn-Wittgenstein, where the appellant could have benefited from Article 56 TFEU (the freedom to provide services). More importantly, the right to a name was formulated as a right to be protected by EU law, presumably covered under 'inter alia' in Article 21 TFEU, in a development consistent with the notion of constitutional dialogue between the CJEU and national courts, and one which 'elevate[s] the constitutional tone of the reasoning highlighting the fundamental right to a name as a presiding principle'. ${ }^{145}$ Although subsequent Opinions of Advocates General and judgments have not devoted much time to a discussion of the legal sources of the right to a name, AG

\footnotetext{
${ }^{142}$ U Šadl, 'Case-Law: Ruiz Zambrano as an Illustration of How the Court of Justice of the European Union Constructs its Legal Arguments' (2013) 19 EuConst 205.

${ }^{143}$ U Šadl and S Hink, 'Precedent in the Sui Generis Legal Order: A Mine Run Approach' (2014) 20 ELJ 544.

${ }^{144}$ For independent rights for minors, see Case C-200/02 Kunqian Catherine Zhu and Man Lavette Chen $v$ Secretary of State for the Home Department ECLI:EU:C:2004:639; and Case C-34/09 Gerardo Ruiz Zambrano v Office national de l'emploi (ONEm) ECLI:EU:C:2011:124. 145 S Iglesias Sánchez, 'The Court and the Charter: The Impact of the Entry into Force of the Lisbon Treaty on the ECJ's Approach to Fundamental Rights' (2012) 49 CML Rev 1565, 1579 .
} 
Jacobs' Opinion in Konstantinidis did so in a very eloquent manner. His arguments about a wider reading of Article 8 of the ECHR (and now also Article 7 of the Charter of Fundamental Rights) coupled with the constitutional traditions of a number of Member States which protect dignity and the right to be given a name, made it clear that the scope of EU law could not exclude the said right. As far as the personal scope is concerned, this was enlarged to encompass non-economically active citizens, including minors, who now have non-derivative, express rights. This idea was introduced in Zhu Chen and later re-emerged in Ruiz Zambrano.

There is thus evidence of the Court's effort to promote and protect one's right to a name, as a means to self-determination and personal identity. However, differently from the ECHR and the ICCPR systems, this right in EU law developed not so much as part and parcel of the right to private life, but qua EU citizenship and consideration of EU citizens as economic actors in the internal market, ie as part of individual economic liberties. Therefore, there is no evidence to suggest the existence of an imperialistic approach, or of 'a linear, strategic action [... $]^{146}$ by which the Court was treating the right to a name as a fundamental right to be weighed against national constitutional traditions. Only the Opinion of Advocate General Jacobs in Konstantinidis had a fundamental rights focus, but the other cases on identity did not engage in a discussion of fundamental rights, and those which did, did so merely en passant. Instead, they followed a more traditional approach, underlying the rest of the CJEU's jurisprudence on free movement: a discrimination test was applied first, and when there was no evidence of different treatment, a market access test was introduced to examine whether there was a serious inconvenience in exercising Treaty rights. Arguably, the market access test, already present in the jurisprudence on other market freedoms, ${ }^{147}$ in conjunction with the inclusion of minors and the 'serious inconvenience' test, makes for an early version of the more recent 'genuine enjoyment' test, formulated in Ruiz Zambrano. Perhaps, in the pre-Lisbon era, the judges were governed by the simple fact that the ECHR was not formally part of the EU legal order and, during the first years of its existence, the Charter of Fundamental Rights of the European Union was non-binding. Surely, reliance on general principles of EU law was already a standard in the Court's jurisprudence, yet at that stage of the European integration the judges at Kirchberg were very much oriented to the development of EU citizenship. Logically, thus, a combination of internal market principles with EU citizenship was a good way forward.

\footnotetext{
${ }^{146}$ D Kostakopoulou, 'Ideas, Norms and European Citizenship: Explaining Institutional Change' (2005) 68 MLR 233, 265.

147 For an overview, see C Barnard, The Substantive Law of the EU. The Four Freedoms (3rd edn, OUP 2010) 19-25.
} 
However, the legally binding Charter introduced a major change in the legal landscape, which the Court of Justice has been exploring consistently, yet at times in a 'sense and sensibility' fashion. ${ }^{148}$ The judges seem to be very much aware of the Charter's potential and, at the same time, the risks that come with it. On the one hand, the binding Charter provides for a long missing (and awaited) bill of rights for the European Union. On the other hand, it can be perceived as a potential vehicle for competence creep and an increase of powers for the European Union. Prima facie, the Member States have fortified their national competences sufficiently with Article 6 TEU and Article 51 of the Charter. Yet, in cases where matters are reserved for the competence of the Member States, they must exercise such competence having regard to EU law. This is a wellestablished doctrine that the Court of Justice developed, for instance in relation to direct taxation. ${ }^{149}$ As far as the Charter of Fundamental Rights is concerned, the Court of Justice famously ruled in Fransson ${ }^{150}$ that the Charter applies whenever the Member States act within the scope of EU law. This does not mean, though, that judges will always rely on the Charter. On the contrary, the choice of legal sources is made carefully, as the Runevič-Vardyn case proves. Left with the choice of which path to follow, the Court of Justice opted for the citizenship/internal market path. This way, it diverted farther from the general trend set by the Strasbourg Court and, by the same token, avoided the risk of being accused of stepping into domestic competence in such a sensitive area and using the Charter as a Trojan horse.

There is no doubt that the principle of attributed powers has dominated the Court's reasoning in the cases on the right to a name. It is notable that the Court has consistently held that the registration of names falls under the discretion of the Member States. Yet, following the line of jurisprudence mentioned above, it made clear that the Member States had to respect EU law and its principles when exercising national sovereignty. It is notable that Lithuania was one of the Member States which submitted views during the Court's proceedings in Sayn-Wittgenstein, endeavouring, on the one hand, to explain why national measures such as

\footnotetext{
${ }^{148}$ See S Peers and others (eds), The EU Charter of Fundamental Rights: A Commentary $(\mathrm{CH}$ Beck-Hart-Nomos 2014).

149 See, inter alia, L Cerioni, The European Union and Direct Taxation: A Solution for a Difficult Relationship (Routledge 2015).

150 Case C-617/10 Åklagaren v Hans Åkerberg Fransson EU:C:2013:105. For an academic appraisal, see, inter alia, M Szwarc, 'Application of the Charter of Fundamental Rights in the Context of Sanctions Imposed by Member States for Infringements of EU Law: Comment on the Fransson Case' (2014) 20 EPL 229; J Vervaele, 'The Application of the EU Charter of Fundamental Rights (CFR) and its Ne bis in idem Principle in the Member States of the EU' (2013) 6 REALaw 113; B Van Bockel and P Wattel, 'New Wine into Old Wineskins: The Scope of the Charter of Fundamental Rights of the EU after Åkerberg Fransson' (2013) 6 EL Rev 866.
} 
those in question in these cases were needed, and, on the other hand, to caution the Court about where the Union's competence lies. One can hardly see the point in such a defensive attitude, given the Court's previous jurisprudence on names and the restraint it exercised there. The CJEU was willing to acknowledge that the spelling of names was an issue of national jurisdiction, but also that it was within its jurisdiction to ensure that the EU law was respected. In some cases it made recommendations, such as in Grunkin and Paul, where the Advocate General suggested that Germany adopt a more flexible law which would allow for the principle of mutual recognition to be upheld.

A second leitmotif of the names cases is the variety of approaches to proportionality. The proportionality test was a central element of the judgment in Runevič-Vardyn, and in the national context it was rather problematic, or at least questionable. In all the cases examined preRunevič-Vardyn, the Court ruled that the national measures were not justified and not proportionate. The only exception was Sayn-Wittgenstein, where the Court was less lenient than Advocate General Sharpston ${ }^{151}$ and ruled in favour of the Austrian measure, because of the constitutional character of the rationale presented by the Austrian government. This seems to have swayed the decision, and is certainly not against the usual distinction between the strict and soft proportionality tests to which the Court resorts when dealing with sensitive issues. ${ }^{152}$ However, the seemingly random manner in which this distinction is being drawn is potentially problematic: in Grunkin and Paul the Court was not convinced by Germany's arguments that their refusal to accept the name GrunkinPaul had to do with protecting the German language; and the measure in Garcia Avello was also dismissed because Belgium could not adequately or satisfactorily justify its actions. In Runevič-Vardyn, however, Lithuania was given more leeway, despite the fact that it seemingly arbitrarily refused to allow Ms Vardyn to have her name spelt as she saw fit.

Arguably, there is an element of incoherence and inadequate citizen protection in the practice of names cases. The varying approach to the proportionality test is characteristic of the Court's tendency not to go against national constitutional courts or principles which are protected

\footnotetext{
${ }^{151}$ Although AG Sharpston acknowledged the legitimacy of Austria's motives, she asked the referring court to consider the inconvenience caused to Ms Sayn-Wittgenstein, taking into account the fact that the contested prefix did not denote nobility in Germany, and that there was a 15-year gap between the issuing of the first birth certificate and the decision to amend her name.

152 Case C-159/90 The Society for the Protection of Unborn Children Ireland Ltd $v$ Stephen Grogan and others ECLI:EU:C:1991:378; Case C-36/02 Omega (n 28); Case C-34/10 Oliver Brüstle v Greenpeace eV ECLI:EU:C:2011:669; Case C-137/09 Marc Michel Josemans v Burgemeester van Maastricht ECLI:EU:C:2010:774; Case C-268/99 Aldona Malgorzata Jany and Others $v$ Staatssecretaris van Justitie, ECLI:EU:C:2001:616.
} 
by the constitutions, ${ }^{153}$ as a safeguard against the possibility of a direct feud with constitutional courts which could undermine the authority and binding character of the Court's judgments. ${ }^{154}$ However, this ad-hoc application of EU law may put into danger legitimate expectations and legal certainly in the long term.

A final leitmotif in the CJEU's cases on names is the lack of exportability of any of these judgments: it may be difficult for national courts in other Member States to see how these judgments may apply in their national setting. Similarly to the cases brought by the Commission against individual Member States where enforcement proceedings rarely have ramifications for other Member States, ${ }^{155}$ the above case law tends to concern either the transposition of EU law into national legal orders, or the invalidity of national laws which contradict EU law. In the former transposition - scenario, the territorial applicability of the cases concern the Member State which failed to adopt a law in accordance with the original EU provision, and, thus, rarely affect other Member States directly, even if they have adopted potentially unsuitable laws. This is because it is highly unlikely that two or more Member States will adopt national laws with the same nature or degree of unsuitability or unlawfulness, and, therefore, each case will have to be judged on an ad hoc basis. The invalidity scenario is more complicated as it can, under certain circumstances, affect more than one Member State. ${ }^{156}$

Runevič-Vardyn is significant because it is an exception to these two scenarios: it does not concern an incorrect transposition of an EU directive, but neither does it concern an expressly contradicting national law. Rather, it demonstrates how an issue derived from a national law may have deeper roots in the complex history of European integration and may affect the relations between Member States, calling for a fine balance between intra-state relations in the EU and the aims of the Court of Justice. On the one hand, the Court must ensure the law of the Union is applied and respected, consistently and uniformly; on the other hand, it

\footnotetext{
153 See Case C-159/90 Grogan (n 152).

${ }^{154}$ D Chalmers and others, European Union Law (2 $2^{\text {nd }}$ edn, CUP 2010) .

${ }^{155}$ A good exception to this is Case C-319/06 Commission of the European Communities $v$ Grand Duchy of Luxembourg ECLI:EU:C:2008:350 and Case C-346/06 Dirk Rüffert v Land Niedersachsen ECLI:EU:C:2008:189. Both cases concerned the transposition of the Posted Workers' Directive in the Luxembourgish and German legal orders, respectively, but, nonetheless, may have effects which will be evident even outside the territories of these countries. See further C Barnard, The UK and Posted Workers: The Effect of Commission v Luxembourg on the Territorial Application of British Labour Law' (2009) 38 ILJ 122.

${ }^{156}$ An indicative example is the case of the acquisition of nationality, where there are two types of national laws: ius sanguinis and ius soli. There is currently no single regime in the EU, which means that one Member State's laws on the acquisition of nationality may easily affect another's immigration policy. See a follow-up to Chen and Zhu where Ireland changed its laws on nationality to avoid further abuse of the existing system.
} 
must allow Member States to safeguard their cultures and languages. ${ }^{157}$ Next to this, these two goals also need be reconciled with the right to protect the rights of EU citizens, one of them now being the right to a name as a form of identity. Rodin, too, sees Runevič-Vardyn as an expression of a tension: on the one hand, language as part of the national constitutional identity via Article 4(2) TEU; and, on the other hand, freedom of movement qua Article $21 \mathrm{TFEU}$, in combination with the right to privacy laid down in Article 7 of the Charter of Fundamental Rights ${ }^{158}$ and the principle of non-discrimination (Articles 18 and 19 TFEU). As the next section will demonstrate, such a balance is not always easy to reach, and the Court may deliver a judgment which is unsatisfying in its effort to please all interested parties.

The presentation and examination of these three leitmotifs has put Runevič-Vardyn in its appropriate judicial context: despite the commonalities, there is still an element of divergence in the case law, and RunevicVardyn is a perfect example of this. As already noted, the Opinion of the Advocate General and the judgment of the Court of Justice differ in terms of tenacity and guidance on the proportionality test: the Court left more discretion to the national court, whereas the Advocate General was more explicit about the alternative of more proportionate measures that would not jeopardise Lithuania's efforts to protect its language and heritage. ${ }^{159}$ It is difficult to understand the Court's argument when the Opinion of the Advocate General covers the question of proportionality sufficiently and demonstrates that the obstacles the citizen in question may encounter can be unnecessarily strict. Perhaps it is just another episode when the Court of Justice took the already mentioned 'sense and sensibility' approach, aiming not to position itself on a collision course with some of the Member States and, at the same time, risk a threat to its legitimacy. It is notable, though, that the Estonian ${ }^{160}$ and Polish ${ }^{161}$ governments agreed with the Advocate General in their observations in Runevič-Vardyn. ${ }^{162}$ This indicates a stand of some Member States towards more humanrights-based treatment of ethnic minorities.

As already discussed, Lithuania took steps to amend its laws at the time of the Runevič-Vardyn dispute. Advocate General Jääskinen suggested that these efforts demonstrate that the national measure failed the

157 See Articles 167 TFEU and 4(2) TEU.

158 S Rodin, 'National Identity and Market Freedoms after the Treaty of Lisbon' (2011) 7 CYELP 11.

159 Paras 84, 87.

160 Para 82.

161 Para 99.

162 Although the AG did not accept Poland's submission, according to which it was possible for institutions of Member States to fail to identify a link between the different spellings on a certificate owing to unfamiliarity with the letters used in the said document. 
EU proportionality test, hence needed reforming in the light of EU law. An alternative reading is that Lithuania considered the judgment and, although favourable, it decided to amend its laws on identity documents anyway. Whichever reading one chooses, the question remains whether the Court should have been more critical (despite the fact that Lithuania decided to revisit its laws), or whether the Court was right in following a cautious approach and allowing the national legislator to make the final decisions. Therefore, one may ask whether the judgment is unnecessarily devoid of any legal bite, and whether this could be amended via citizenship and fundamental rights paradigms.

One explanation is that the Court was trying to respect Lithuanian's right to protect its heritage: the reason why it afforded the national court such leeway is because the aforementioned right was of a constitutional nature. This is supported by other examples of similar national protectionism to which the Court has not objected in the past, such as the protection of a national language (Case C-379/87 Groener), abortion (Case C-159/90 Grogan) or human dignity (Case C-36/02 Omega; Case C-34/10 Brüstle). However, one could also argue that there is the outstanding issue of common sense: the Lithuanian authorities used the character ' $\mathrm{W}$ ' in the case of Mr Wardyn, meaning that it is technically possible to include letters of a non-Lithuanian Latin-based alphabet in marriage certificates. This cannot be explained by saying that Ms Runevič-Vardyn was a Lithuanian national and thus her case is one of reverse discrimination: while certain elements of the case were confined within Lithuanian territory, there was a sufficient link with the exercise of EU rights because the family lived in Belgium.

This divergence in potential readings of the Court's judgment is more inexplicable when the earlier case law is considered. Although the Runevič-Vardyn judgment made references to previous names cases, it did so only in order to reiterate the maxim that the decisions regarding names are national ones, but should nevertheless respect EU law. Apart from this obvious admission, the remainder of the case law actually provides different advice from the final outcome in Runevič-Vardyn. In Garcia Avello, the Court found it impossible to accept Belgium's practice because it had no objective justification. In Grunkin and Paul, just like RunevičVardyn, the national government used the protection of language as a justification. Here, the Court did not accept that a composite surname was incompatible with protecting the language, making Runevič-Vardyn hard to fathom. How would the use of one letter dilute a national language, or 'the nation's identity, [...] integration of citizens, [...] the expression of national sovereignty, the indivisibility of the State [...],, ${ }^{163}$ when

163 Para 84. 
there was no total general ban on using any Latin letters not existing in the Lithuanian alphabet?

Finally, although in Runevič-Vardyn the Court refers to citizenship and its fundamental status, ${ }^{164}$ it does so only while discussing the applicable EU law provisions. The remainder of the judgment is preoccupied with the breach of EU law, while the proportionality test is rather thin. Although the rights deriving from the status of citizenship are described as fundamental, there is an implicit conviction on behalf of the Court that the right to a name, derivative as it might be, and the right to family life for EU citizens are both subservient to the Lithuanian constitutional tradition. This hierarchical treatment is inherently problematic, not least because of the confusion it creates vis-à-vis supremacy of EU law, a situation which has been delightfully likened to the premise of the play 'Who's Afraid of Virginia Woolf'. ${ }^{165}$ As a corollary, citizenship in RunevičVardyn is viewed as a mere codification of pre-existing (market) rights, and lacks a Charter-based fundamental rights dimension.

\subsection{European Integration and European identities: quo vadis?}

So far, this article has examined the case law on the right to a name, demonstrated how Runevič-Vardyn fits within that framework, and established the historical and political background within which the case emerged and the impact it has had on Lithuanian legislative reform. Based on the arguments made thus far, two axes of analysis can be deduced. Firstly, whether the current state of affairs regarding the fundamental rights balancing act is working; secondly, how a conceptual framework with a focus on a discussion of citizenship as a facilitator for integration could provide an answer to the said balancing act. These are the questions to which we now turn.

With regard to the first element, there were five Member States which submitted observations in Runevič-Vardyn, four of which joined the EU in 2004: the Czech Republic, Estonia, Latvia, and Slovakia. Most of them have problems with protecting the rights of their nationals who belong to ethnic minorities. ${ }^{166}$ The disagreements on minority rights in Lithuania and Poland, as outlined in Runevič-Vardyn, are resonant in international

\footnotetext{
${ }^{164}$ Case C-413/99 Baumbast and $R \quad v$ Secretary of State for the Home Department ECLI:EU:C:2002:493; Case C-135/08 Janko Rottman $v$ Freistaat Bayern ECLI:EU:C:2010:104.

165 D Sarmiento, 'Who's Afraid of the Charter? The Court of Justice, National Courts and the New Framework of Fundamental Rights Protection in Europe' (2013) 50 CML Rev 1267.

166 The Roma in the Czech Republic and Slovakia; the Hungarian minority in Slovakia; the Russian minority in Latvia and Estonia. See, inter alia, K Topidi, The Limits of EU Conditionality: Minority Rights in Slovakia' (2003) 1 JEMIE 1; DJ Smith, 'Minority Rights, Multiculturalism and EU Enlargement: The Case of Estonia' (2003) 1 JEMIE 1; P Vermeersch, 'EU Enlargement and Minority Rights Policies in Central Europe: Explaining Policy Shifts in the Czech Republic, Hungary and Poland' (2003) 1 JEMIE 1.
} 
relations between other Member States, too. It is sufficient to point out Hungary $v$ Slovakia ${ }^{167}$ to illustrate just how difficult it is to reconcile the recent history of the post-communist democracies in the EU. ${ }^{168}$ The latter case concerned Slovakia's refusal to allow the Hungarian President to enter the country, because the purpose of his visit was to give a speech in an area which housed a large Hungarian minority. This was not helped by the fact that the visit was scheduled for 21 August, the anniversary of the Warsaw Pact invasion of the then Czechoslovakia. The Court based its judgment on international law rules governing visits of heads of states, thus limiting the scope of EU law, a finding that goes against its own precedents'169 both in terms of the supremacy of EU law over international law and on the fundamental status of citizenship. Moreover, the judgments in Hungary $v$ Slovakia and Runevič-Vardyn seem to have been separated from their historical workings, and show signs of functionalism as opposed to teleology: in both cases, the Court tried to find the least politically upsetting way out. Runevič-Vardyn illustrates perfectly the Court's problematic approach to citizenship and fundamental rights protection in how to reconcile national constitutional values with the European Union legal order, but also national traditions and idiosyncrasies. Although the EU has taught Member States to cooperate to an unprecedented degree and to do so without being blinded by purely national interests, ${ }^{170}$ there is still an underlying impression that Member States see EU citizenship and its accompanying rights as a type of superimposition of EU law on their national legal orders.

While minority rights are now protected by the Charter's equality provisions, ${ }^{171}$ it is debatable whether these rights would be deemed as important as the protection of a national language. ${ }^{172}$ The question, of course, is whether this balance is acceptable and, if not, how this state of affairs can be corrected. Admittedly, one could easily argue that the Court has in the past followed relatively sound legal reasoning to justify free movement derogations based on constitutional traditions, or that Ar-

\footnotetext{
167 Case C-364/10 Hungary $v$ Slovak Republic ECLI:EU:C:2012:63. For a commentary, see M Filippin, 'A Change for Future Intra-European Diplomatic Relations? Case C-364/10 Hungary v Slovak Republic, Judgment of 16 October 2012, not yet reported' (2013) 20 MJECL 120; LS Rossi, 'EU Citizenship and the Free Movement of Heads of State: Hungary v Slovak Republic' (2013) 50 CML Rev 1451.

168 For an extensive discussion on minority rights in the EU and in Europe, see GN Toggenburg, Minority Protection and the Enlarged European Union: The Way Forward (LGI Books 2004).

169 Rossi (n 167) 1460.

170 T Kostakopoulou, 'Towards a Theory of Constructive Citizenship in Europe' (1996) 4 JPP 337.

${ }^{171}$ Article 21(1) of the Charter of Fundamental Rights.

${ }^{172}$ H Van Eijken, 'Case C-391/09 Malgožata Runevič-Vardyn and Łukasz Paweł Wardyn $v$ Vilniaus Miesto Savivaldybes Administracija and Others, Judgment of the Court (Second Chamber) of 12 May 2011' (2012) 49 CML Rev 809.
} 
ticle 4(2) TEU which ensures that the Union respects the identities of the Member States - which include a national language - allows the Court to afford Member States considerable leeway. However, the cases mentioned previously, Grogan and Groener, were decided prior to the adoption of the Charter, and the Court is proving to be reluctant to use the Charter as a means to challenge previous precedent and introduce a new balance between fundamental rights and principles and national constitutional traditions. There is a danger that by prioritising the latter, the supremacy of EU law may be questioned. EU law has been enjoying supremacy since Costa $v$ ENEL, ${ }^{173}$ but the Court is often very reluctant to challenge constitutional courts or constitutional traditions (the Omega Spielhalen and Brüstle cases) despite it expressly arguing that 'rules of national law, even of a constitutional order, cannot be allowed to undermine the effectiveness of EU Law on the territory of that State'. ${ }^{174}$ This was painfully visible in Melloni, where the hierarchical position of the Charter of Fundamental Rights was - ever so controversially - elevated. ${ }^{175}$ While supremacy of EU fundamental rights may remain a 'gentlemen's agreement'176 in the eyes of some national constitutional courts, this cannot distract us from the fact that although the Court usually uses common constitutional traditions to qualify fundamental freedoms, this does not mean that every tradition, no matter how central to a constitution, automatically qualifies for common constitutional tradition status. The only consolation is that the Court's current restrictive approach can find some support in the issue of EU competences: the EU has no legislative competence to set standards on minority protection (including the rules on how to spell individual names), except the prohibition of non-discrimination that is limited to the field of employment. ${ }^{177}$ There is, therefore, a considerable, and difficult to explain, gap in the legislation. ${ }^{178}$

Given that fundamental rights may be a politically sensitive area for the Court to intervene in, the authors suggest that a solution would be to rely on EU citizenship as a facilitator for integration and for the promotion of the European project, a project whose evolution is deeply rooted in an idealistic interpretation of its founders' original aspirations, as opposed to a concrete idea of justice and equality through citizen-

\footnotetext{
${ }^{173}$ Case C-6/64 Flaminio Costa $v$ ENEL ECLI:EU:C:1964:66.

${ }^{174}$ Case C-399/11 Stefano Melloni v Ministerio Fiscal ECLI:EU:C:2013:107, para 59.

175 For an academic appraisal, see, inter alia, N De Boer, 'Addressing Rights Divergence Under the Charter: Melloni' (2013) 50 CML Rev 1083.

${ }^{176}$ LS Rossi, 'How Fundamental Are Fundamental Principles? Primacy and Fundamental Rights after Lisbon' (2008) 27 YEL 65.

177 T Ahmed, The Impact of EU Law on Minority Rights (Hart Publishing 2011).

${ }^{178}$ A similar lack of legislative competence exists for social rights. The Court has been criticised for reaching too deep into national competences with regard to the rights to strike and collective bargaining in light of Art 153(5) TFEU. See G De Búrca, 'The Principle of Subsidiarity and the Court of Justice as an Institutional Actor' (1998) 36 JCMS 217, 221.
} 
ship. EU citizenship can resolve the problem created by the aforementioned balancing act, because it can offer adequate fundamental rights protection without upsetting the EU/Member State balance of power, or stretching EU competences. More particularly, instead of allowing the Member States to interpret the citizenship provisions as they see fit, the Court can convincingly use the effet utile argument and argue that EU citizenship cannot function effectively without full incorporation of its potential into the acquis; otherwise, the rights deriving from one's status as citizen would be as good as removed. ${ }^{179}$ In other words, citizenship as a facilitator for integration could prevent a situation where there are two realities for EU citizens: one rooted in their national citizenship, and one in highly ineffective, residence-based EU citizenship, which is triggered when there is an intra-border movement (an 'absurd'180 requirement), a deprivation of the genuine enjoyment of rights, or dismissed in favour of national constitutional traditions, all situations which undermine the ideas of substantive equality.

The merit of this approach is twofold: it would end the current preoccupation with free movement as the only core of citizenship; ${ }^{181}$ and it would also address the current criticisms which suggest that the EU's democratic workings remain unsatisfactory, if not regressive, owing to a concentration of powers on institutions whose membership is not a result of direct democracy. ${ }^{182}$ However, this does not take into consideration the view that the Court is legitimising the Union through justice. ${ }^{183}$ Even if one argued that the Court was not democratically endowed to perform what is essentially a federalising role, ${ }^{184}$ it would be unfair not to recognise the CJEU's role 'as [a] reliable agen[t] for equitable settlements within and above the nation-state', ${ }^{185}$ or its role as an institutionalised enforcer of EU law. ${ }^{186}$

\footnotetext{
${ }^{179}$ D Kostakopoulou, 'When EU Citizens Become Foreigners' (2014) 20 ELJ 447.

180 D Kochenov, 'The Citizenship Paradigm' (2013) 15 CYELS 196.

181 S O'Leary, 'The Free Movement of Persons and Services' in P Craig and G De Búrca (eds), The Evolution of EU Law (OUP 1999).

182 A José Menéndez, 'Editorial: A European Union in Constitutional Mutation?' (2014) 20 ELJ 127.

${ }^{183}$ G De Búrca, 'The Quest for Legitimacy in the European Union' (1996) 59 MLR 349; A Wiener and V Della Sala, 'Constitution-Making and Citizenship Practice: Bridging the Democracy Gap in The EU?’ (1997) 35 JCMS 595; J Neyer, 'Justice, Not Democracy: Legitimacy in the European Union' (2010) 48 JCMS 903.

${ }^{184}$ K Lenaerts, “Civis Europaeus Sum”: From the Cross-Border Link to the Status of Citizen of the Union' (2011) 3 FMW 6.

${ }^{185}$ D Kostakopoulou 'The European Court of Justice, Member State Autonomy and European Union Citizenship: Conjunctions and Disjunctions' in B de Witte and HW Micklitz (eds), The European Court of Justice and the Autonomy of the Member States (Intersentia 2012) 175.

${ }^{186}$ L Conant, Justice Contained: Law and Politics in the European Union (CUP 2002).
} 
The current understanding of citizenship as a distinct level of belonging, 'a matter of convenience', ${ }^{187}$ is rooted in the at least currently unfounded ${ }^{188}$ fear that EU citizenship may replace national ones, which is a corollary of approaching membership exclusively from a statist perspective, which is bound to be unworkable and unproductive. ${ }^{189}$ This was evident in Denmark's declaration submitted to other Member States during negotiations of the Treaty of Maastricht that the rights attached to EU citizenship 'do not in any way take the place of national citizenship', a concept which 'will be settled solely by reference to the national law of the Member States concerned', a fear possibly deriving from fact that in Danish eyes, nationality and citizenship are not separate concepts, although this is by no means exclusive to Denmark. ${ }^{190}$

Moreover, the Court's case law on EU citizenship, ${ }^{191}$ and its influence on the EU's secondary law in the form of Directive 2004/38/EC, ${ }^{192}$ has made it clear that the concept is one closer to the idea of residence than that of belonging to a specific national group, because EU citizenship has created a community of EU citizens, not bequeathed one. Therefore, there is evidence of an unconscious judicially sponsored detachment of EU citizenship from national allegiances, which means that Ms RunevičVardyn's right had little to do with her national loyalties and more to do with her links to a European polity as a whole. ${ }^{193}$ This is another iteration of the concept of independent EU citizenship, one based on the more inclusive and fair concept of membership-by-residence, and one which should affect the evolution of citizenship in the near future. This idea of a common European space has been present in Opinions submitted by a number of Advocates General in the past, and certainly after the 2004 enlargement, ${ }^{194}$ and the authors argue that the Court should be less willing to offer unqualified support to national loyalties.

187 J Shaw, 'The Interpretation of European Union Citizenship' (1998) 61 MLR 293.

188 C Closa, 'Citizenship of the Union and Nationality of the Member States' in D O'Keefe and P Twomey (eds), Legal Issues of the Maastricht Treaty (Chancery Law Publishing 1993).

189 T Kostakopoulou, 'Nested "Old" and "New" Citizenships in the European Union: Bringing Out the Complexity' (1999) 5 CJEL 389.

190 This eventually led to a revision of Article 20 of the EC Treaty by the Treaty of Amsterdam.

${ }^{191}$ See further, inter alia, M Dougan, The Constitutional Dimensions to the Case Law on Union Citizenship' (2006) 31 EL Rev 613; D Kostakopoulou, 'European Union Citizenship: Writing the Future' (2007) 13 ELJ 623; F Wollenschläger, 'A New Fundamental Freedom Beyond Market Integration: Union Citizenship and its Dynamics for Shifting the Economic Paradigm of European Integration' (2011) 17 ELJ 1.

192 Directive 2004/38 on the right of citizens of the Union and their family members to move and reside freely within the territory of the Member States [2004] OJ L158/77. For a detailed analysis, see E Guild and others, The EU Citizenship Directive: A Commentary (OUP 2014).

${ }^{193}$ Kostakopoulou (n 185).

${ }^{194}$ See the Opinion of AG Sharpston in Case C-34/09 Zambrano ECLI:EU:C:2011:124, and Advocate General Maduro in Case C-499/06 Nerkowska ECLI:EU:C:2008:300. 
Equally, the principle of substantive equality could form part of our view of what constitutes proper balance. The non-discrimination provisions have direct effect; therefore, if read in conjunction with Articles 20 and 21 TFEU, they could address situations of reverse discrimination, ${ }^{195}$ such as the element of Runevič-Vardyn which concerns a claim against the applicants' home country. ${ }^{196}$ These Treaty articles could also ensure that EU citizenship is approached as an independent concept that should not be regarded in terms of subjugation, hierarchies, or additionality, thereby weakening the odd caveat which currently makes EU citizenship provisions subject to limitations found in the Treaty and secondary legislation. ${ }^{197}$ This lack of subjugation and the resulting independence of EU citizenship will not only make its equality element more substantive, but will also affect the procedural aspect of applying EU citizenship: the combination of substantive and procedural is what will make EU citizenship truly a tool for integration. ${ }^{198}$ If allowing an EU citizen to initiate a claim against their Member State of origin sounds beyond what the Treaty's wording allows, despite the CJEU judgments suggesting otherwise, ${ }^{199}$ the combined reading of Articles 18, 20, and 21 TFEU could act as a means towards a more equal citizenship status and would not have worrying implications, as it would not lead to an unqualified review of national laws. ${ }^{200}$

Even if EU residence-based citizenship failed to assist Ms RunevičVardyn in this instance, and even though its current configuration is less than ideal, this does not mean it should be dismissed in the future. ${ }^{201}$ Rather, any perceived failure should instead be seen as a 'consequence of institutional failure rather than a cause of it', ${ }^{202}$ and should thus act as a catalyst for change and a re-organisation and re-conceptualisation of EU citizenship. The current system is rather fragmented, which becomes

\footnotetext{
${ }^{195}$ H De Waele, 'EU Citizenship: Revisiting its Meaning, Place and Potential' (2010) 12 EJML 319.

196 See also Case C-33/07 Ministerul Administrației şi Internelor - Direcția Generală de Paşapoarte Bucureşti v Gheorghe Jipa ECLI:EU:C:2008:396. For an academic appraisal, see A Łazowski, “Darling You Are Not Going Anywhere": The Right to Exit in EU Law' (2015) 40 EL Rev (forthcoming).

${ }^{197} R v$ Secretary of State for the Home Department Ex p. Vitale [1996] 2 CMLR 587.

198 See Kochenov (n 180).

199 Joined cases C-11/06 and C-12/06 Rhiannon Morgan v Bezirksregierung Köln (C-11/06) and Iris Bucher v Landrat des Kreises Düren (C-12/06) ECLI:EU:C:2007:626.

${ }^{200}$ E Spaventa, 'Seeing the Woods Despite the Trees? On the Scope of Union Citizenship and its Constitutional Effects' (2008) 45 CML Rev 13.

${ }^{201}$ M Everson, 'The Legacy of the Market Citizen' in J Shaw and G More (eds), New Legal Dynamics of European Union (OUP 1995); JHH Weiler, 'Citizenship and Human Rights' in JA Winter and others (eds), Reforming the Treaty on European Union (Kluwer 1996); C Jacqueson, 'Union Citizenship and the Court of Justice: Something New Under the Sun? Towards Social Citizenship' (2002) 27 EL Rev 260.

202 A Przeworski (ed), Sustainable Democracy (CUP 1995).
} 
clearer if one juxtaposes fundamental rights cases on names with cases which concern the implications of the protection of fundamental rights, such as Rottmann. If one adds to this mix the national political idiosyncrasies and feuds to which this article has referred, then it is obvious that the current level of protection is more akin to a mosaic, differing from state to state, rather than to a coherently engineered architectural creation.

To summarise, this final section has endeavoured to argue that the importance of EU citizenship - and, therefore, its effects - can very simply be elevated, where EU citizenship provisions are used legitimately and transparently as the rationale for extending the scope of EU law. EU citizenship law can be interpreted as being able to qualify national competences, ${ }^{203}$ which is not unprecedented: fundamental rights protection is understood to go beyond the bare minimum, ${ }^{204}$ even in sensitive areas, ${ }^{205}$ and any limitations to its effectiveness have to be suitable and necessary, and also subject to EU fundamental rights review. ${ }^{206}$ In this way, EU citizenship can be constructed as a fundamental status going beyond what is strictly necessary, in other words, embracing its full potential. In adopting such an interpretation, the Court would not be accused of judicial activism, because this approach would require the Court to engage in a more transparent line of reasoning, which in turn would be more legitimising. Thus it would 'strengthen the primacy of EU law by [...] stat[ing] the reasons why it decided to follow (or depart from) the level of fundamental rights protection provided for by the member states' constitutions', ${ }^{207}$ a type of comparative effectiveness test. The legitimacy-inducing rights which accompany citizenship are already used by the Commission to emphasise the significance of citizenship in transforming ideas of belonging, the notion of 'Other', and civic membership. ${ }^{208}$ Furthermore, some of the current jurisdictional tests, such as the cross-border movement requirement, were established by the Court without textual basis in the Treaties, ${ }^{209}$ so the Court should not be unwilling to establish a progressive doctrine, in keeping with the evolution of the

\footnotetext{
${ }^{203}$ Rottmann introduced the idea of qualifying important national competences, which up to that point were believed to be solely within the Member States' control.

${ }^{204}$ Case C-260/89 Elliniki Radiophonia Tiléorassi AE and Panellinia Omospondia Syllogon Prossopikou v Dimotiki Etairia Pliroforissis and Sotirios Kouvelas and Nicolaos Avdellas and others ECLI:EU:C:1991:254.

205 Sarmiento (n 165).

206 Cases C-36/02 Omega (n 28) and C-208/09 Sayn-Wittgenstein (n 4).

${ }^{207} \mathrm{~K}$ Lenaerts, 'Exploring the Limits of the EU Charter of Fundamental Rights' (2012) 8 EuConst 375, 386.

${ }^{208}$ P Magnette, 'How Can One Be European? Reflections on the Pillars of European Civic Identity' (2007) 13 ELJ 664.

${ }^{209}$ D Kochenov and R Plender, 'EU Citizenship: From an Incipient Form to an Incipient Substance? The Discovery of the Treaty Text' (2012) 37 EL Rev 369.
} 
Union. EU citizenship, as any citizenship concept, is a 'dynamic one', ${ }^{210}$ subject to changes 'in response to changing conceptions of membership and evolving definitions of community'. ${ }^{211}$ Therefore, the need for a new, residence-based citizenship model, one offering more protection and one closely linked to fundamental rights at the place of residence, is not pie in the sky or uncalled for; instead, it is a response to a multi-layered Union with multiple ideas of belonging and a number of inter-locking legal orders. The EU has evolved into being more than a sum of its Member States; its citizenship, a wonderfully novel concept, should follow suit.

\section{Conclusions}

The future of European integration is facing problems, not only economic (the Euro crisis), and political, but also societal, such as multicultural, ethnic and religious differences, and the clashing individual identities of EU citizens. The complexity, as well as the multiplicity, of such problems raises serious doubts about the success (short- and long-term) of the European project. Looking at the broader picture, it seems that Runevič-Vardyn was the trigger which escalated the political differences of politicians ${ }^{212}$ in Lithuania and Poland, damaging diplomatic relations between the two Member States. Thus, as the foreign experts note, 'the Polish-Lithuanian theatre of the absurd has more to do with narcissistic differences rather than geopolitical and cultural affinity'. ${ }^{213}$ Given there is very low acceptance that non-discrimination on the grounds of nationality exists in Eastern European countries, ${ }^{214}$ one can only imagine what this may mean for the treatment of ethnic minorities in many Member States in this part of Europe. With the rise of the right-wing parties evidenced by the results of the 2014 European Parliament elections, this causes concern regarding the lack of acceptance and accommodation of the Other in those Member States that see themselves as based on the 'restrictive construction of the Volk and a steep rise in petty nationalism,

\footnotetext{
${ }^{210}$ D O'Keefe, 'Union Citizenship' in D O'Keefe and P Twomey (eds), Legal Issues of the Maastricht Treaty (Chancery Law Publishing 1993).

211 Kostakopoulou (n 170) 339.

212 Poland's former President Bronislaw Komorowski did not have big ambitions to remarkably affect the foreign policy implemented by the Tusk government. In both Polish and Lithuanian media, the personality of Sikorski as Poland's Foreign Minister was posited as one of the main factors which brought about a chill in relations between Poland and Lithuania. From a domestic policy matter, the competition of the two right-wing parties (Law and Justice and Civic Platform) grew into a foreign policy issue. See Dambrauskaitè and others (n 46) 125, 132.

213 ibid 101. See also VS Gira, 'Lithuanian-Polish Bilateral Relations: The Issues of Dispute' (2011) 2 East Pulse.

214 J Gerhards, 'Free to Move? The Acceptance of Free Movement of Labour and Non Discrimination among Citizens of Europe' (2008) 10 Eur Soc 121, 127 (figure 1).
} 
which is state-sanctioned and presented as a norm'. ${ }^{215}$ This mind-set is dangerous not only for individual Member States, but for the whole European project and calls for a more inclusive concept of European, as well as national, citizenship. In the words of Lithuanian poet Tomas Venclova, whose native languages are Lithuanian, Polish, and Russian:

when we are Europeans not only in word but in deed - in other words, a self-reliant, self-critical people who respect the Other, able and thirsting to grasp our own essence in conjunction with traditions that are not our own - then, more than ever before, we will be Lithuanians as well. ${ }^{216}$

All these socio-political difficulties notwithstanding, we believe that in Runevič-Vardyn the Court of Justice adopted a 'safe' approach to the issue because of its sensitivity in many post-Soviet Member States and the lack of common practice or EU-wide harmonised legislation on the spelling of names. The Court has had to face similar challenges in the past, and the approach in this case is consistent with its cautious modus operandi. However, this should not distract us from the fact that the Court will inevitably have to address this gap in ethnic minority EU citizen protection. It is neither appropriate nor feasible to do so by introducing a test to discern which national constitutional traditional is worthy of becoming a common tradition, but the Court can certainly act in favour of a more inclusive and independent concept of EU citizenship. The most important step in this direction is to encourage legal reform towards allinclusive substantive equality ${ }^{217}$ at national level - not only in Lithuania, but also in other Member States which face problems in protecting minority rights. One can only hope that this might be achieved for the benefit of the substantive equality of all European citizens, which is rooted in the cosmopolitan character of EU citizenship, underpinned by the Charter. Even if one were convinced that the EU is not 'citizenship-capable', ${ }^{218}$ it is time to start viewing the EU's lack of demos and non-conformity to statist paradigms as its advantage in creating a new citizenship, and not as its weakness.

\footnotetext{
215 D Kochenov, 'Book Review. From Soviet Republics to EU Member States by Peter Van Elsuwege' (2009) 20 EJIL 1324.

216 T Venclova, 'The Best Way to Love Our Identity' (2006) 52 Lituanus.

217 D Kochenov, 'Equality Across the Legal Orders; Or Voiding EU Citizenship of Content' in E Guild and others (eds), The Reconceptualisation of European Citizenship (Martinus Nijhoff 2014).

${ }^{218}$ NN Shuibhne, 'The Resilience of EU Market Citizenship' (2010) 47 CML Rev 1597, 1598.
} 